\title{
Fluconazole-Pyridoxine Bis-Triazolium Compounds with Potent Activity against Pathogenic Bacteria and Fungi Including Their Biofilm-Embedded Forms
}

\author{
Marsel R. Garipov, ${ }^{1}$ Roman S. Pavelyev, ${ }^{1}$ Svetlana A. Lisovskaya, ${ }^{2}$ \\ Elena V. Nikitina, ${ }^{1}$ Airat R. Kayumov, ${ }^{1}$ Alina E. Sabirova, ${ }^{1}$ Oksana V. Bondar, ${ }^{1}$ \\ Albina G. Malanyeva, ${ }^{1}$ Alexander M. Aimaletdinov, ${ }^{1}$ Alfia G. Iksanova, ${ }^{1}$ \\ Konstantin V. Balakin, ${ }^{1,3}$ and Yurii G. Shtyrlin ${ }^{1}$ \\ ${ }^{1}$ Kazan (Volga Region) Federal University, Kremlyovskaya 18, Kazan 420008, Russia \\ ${ }^{2}$ Kazan Scientific and Research Institute of Epidemiology and Microbiology, Bolshaya Krasnaya 67, Kazan 420015, Russia \\ ${ }^{3}$ I.M. Sechenov First Moscow State Medical University, Trubetskaya 8, Bldg 2, Moscow 119991, Russia \\ Correspondence should be addressed to Yurii G. Shtyrlin; yurii.shtyrlin@gmail.com
}

Received 4 September 2017; Accepted 21 November 2017; Published 27 December 2017

Academic Editor: Daniela De Vita

Copyright (C) 2017 Marsel R. Garipov et al. This is an open access article distributed under the Creative Commons Attribution License, which permits unrestricted use, distribution, and reproduction in any medium, provided the original work is properly cited.

\begin{abstract}
Two novel quaternary ammonium salts, bis-triazolium derivatives of fluconazole and pyridoxine, were synthesized by reaction of fluconazole with pyridoxine-based synthetic intermediates. The leading compound demonstrated pronounced antimycotic and antibacterial in vitro activity, comparable to or exceeding that of the reference antifungal (fluconazole, terbinafine) and antibacterial/antiseptic (miramistin, benzalkonium chloride) agents. In contrast to many antimicrobials, the leading compound was also active against biofilm-embedded staphylococci and Escherichia coli. While no biofilm structure destruction occurred, all compounds were able to diffuse into the matrix and reduce the number of colony-forming units by three orders of magnitude at $16 \times$ MBC. The leading compound was significantly less toxic than miramistin and benzalkonium chloride and more toxic than the reference antifungal drugs. The obtained results make the described chemotype a promising starting point for the development of new broad-spectrum antimicrobial therapies with powerful effect on fungal and bacterial pathogens including their biofilmembedded forms.
\end{abstract}

\section{Introduction}

In the last decades, there is drastic increase of diseases caused by microscopic fungi. Among them, dermatomycetes, such as Trichophyton spp., which are the main causative agents for dermatomycoses in both immunocompetent and immunocompromised patients, become a serious clinical problem. The widespread distribution of microscopic fungi in the natural environment results in multiple direct contacts of humans with the pathogens. The anthropogenic factors also contribute to accumulation of hazardous fungal strains in the environment and to an increased number of immunodeficient people prone to secondary mycoses caused by conditionally pathogenic fungi including Aspergillus, Rhizopus, Fusarium, Paecilomyces, Candida, and Rhodotorula [1].
Candida albicans is one of the most widely distributed dimorphic microscopic fungi growing as both yeast and filamentous cells and causing deep and cutaneous forms of candidiasis in humans being responsible for $50-90 \%$ of all cases of candidiasis in humans [2]. Systemic fungal infections (fungemias) including those which are caused by C. albicans have emerged as important causes of morbidity and mortality in immunocompromised patients (e.g., patients with AIDS, after cancer chemotherapy, and organ or bone marrow transplantation) $[3,4]$.

C. albicans possesses well developed mechanisms of adaptation, which can significantly enhance their pathogenicity. One of such mechanisms is forming the biofilms on tissues and abiotic surfaces and implants that dramatically increase 
the pathogen's resistance to antifungal agents $[5,6]$. Within the biofilm, fungal cells are protected from the immune system of the host, antimycotics, and antiseptic agents. In biofilms, the specific fungal populations survive with the most resistant and virulent phenotypes formed due to a prolonged action of biological and chemical agents. As a result, the cells released from biofilms often cause acute fungal infections highly resistant to the treatment. Candidiasis commonly occurs on mucous membranes of mouth, vagina, and other organs, where C. albicans forms rigid biofilms, which have been considered as one of the critical factors providing fungal resistance to traditional antimycotic drugs, including azoles, polyenes, and echinocandins [7].

Microbial associations, natural communities of several microorganisms, represent additional serious clinical problem $[8,9]$. Certain types of microorganisms involved into the association and resistant to antimicrobial agents enhance the vital activity and resistance of other species as a result of the interaction. As a result, such associations are very resistant to various factors. Many patients with chronic skin mycoses are often infected with various fungal strains belonging to different species, genera, and even classes. Therefore, the effective antifungal drug should have a systemic action, which warrants its efficient penetration into damaged organs and tissues and the fungal mono- and polymicrobial biofilms.

There are a wide number of antimycotic drugs in current clinical practice [10]. One of the most popular azole compounds, fluconazole, is a first-generation fungistatic triazole often used for the treatment of cutaneous and other forms of candidiasis [11]. Fluconazole inhibits ergosterol synthesis and thus alters membranes of fungal cell. Fluconazole is actively used for the treatment of Candida infections and possesses favorable safety profile and good pharmacokinetic characteristics. However, its narrow antifungal spectrum, in particular, low activity against non-Candida fungi, has greatly affected its therapeutic efficacy in clinic [12]. There is also extensive documentation of intrinsic and developed resistance to azole antifungals among Candida species [13]. In addition, poor water solubility of fluconazole makes it problematic to develop effective delivery forms for intravenous administration. These issues stimulated many studies associated with structural modification of fluconazole, including esterification of hydroxyl group and modification of 2,4-difluorobenzyl and triazolyl moiety, aimed to improve its water solubility and/or antimicrobial spectrum (e.g., [1416]). A successful example was fosfluconazole, a prodrug developed for the treatment of infections caused by Candida albicans and Cryptococcus, which exhibited broader antifungal activity spectrum than fluconazole [17].

In a more general context, several studies have revealed that the transformation of triazolyl ring into triazolium could result in enhanced antimicrobial action. Triazolium is able to form additional hydrogen bonds and produce electrostatic interaction with biological targets, and these structural features can affect the diffusion and interaction in bacterial tissues with the enhancement of water solubility and membrane permeability [18]. Thus, quaternization of $\mathrm{N}-4$ position of triazole ring in fluconazole produced the corresponding triazolium compounds, which demonstrated promising antibacterial potential [19].

In light of the described promising results, it was reasonable to explore further structural modifications of fluconazole. In this work, we have obtained two novel quaternary ammonium salts, bis-triazolium derivatives of fluconazole and pyridoxine. The introduction of pyridoxine (vitamin B6) moiety into the developed hybrid structures can potentially enhance the transmembrane transport of the whole constructs via several possible mechanisms like either specific pyridoxine transporters in cellular membranes [20] or recognition of pyridoxine-modified molecules by the cell as endogenous [21]. Another practical reason for introduction of pyridoxine-based cyclic acetals into the developed hybrids is the possibility of easily varying the acetal substituents in order to modify lipophilicity, steric parameters, and other physicochemical properties of the obtained structures.

\section{Materials and Methods}

2.1. Synthetic Procedures. ${ }^{1} \mathrm{H}$ and ${ }^{13} \mathrm{C}$ NMR spectra were recorded on a Bruker AVANCE 400 at operating frequency of 400 and $101.56 \mathrm{MHz}$, respectively. Chemical shifts were measured with reference to the residual protons of the solvent (DMSO- $\mathrm{d}_{6},{ }^{1} \mathrm{H}, 2.50 \mathrm{ppm},{ }^{13} \mathrm{C}, 39.52 \mathrm{ppm} ; \mathrm{CDCl}_{3}$, $\left.{ }^{1} \mathrm{H}, 7.26 \mathrm{ppm},{ }^{13} \mathrm{C}, 77.16 \mathrm{ppm}\right)$. Coupling constants $(\mathrm{J})$ are given in Hertz $(\mathrm{Hz})$. The following abbreviations are used to describe coupling: $\mathrm{s}=$ singlet; $\mathrm{d}=$ doublet; $\mathrm{t}=$ triplet; $\mathrm{m}=$ multiplet; $\mathrm{q}=$ quartet; $\mathrm{br} \mathrm{s}=$ broad singlet; $\mathrm{qd}=$ quartet of doublets; $\mathrm{AB}=\mathrm{AB}$ system. Melting points were determined using a Stanford Research Systems MPA-100 OptiMelt melting point apparatus and are uncorrected. For TLC analysis, silica gel plates from Sorbfil (Krasnodar, Russia) were used with UV light (t, $254 \mathrm{~nm} / 365 \mathrm{~nm}$ ) or iron (III) chloride as developing agent. Column chromatography was performed on silica gel (60-200 mesh) from Acros or reversed phase chromatography on chromatograph PuriFlash 450 (PF-15C18HP column, Interchim). HRMS mass spectra were obtained on a quadrupole time-of-flight ( $t$, qTOF) AB Sciex Triple TOF 5600 mass spectrometer using turbo-ion spray source (nebulizer gas nitrogen, a positive ionization polarity, needle voltage $5500 \mathrm{~V}$ ). Recording of the spectra was performed in "TOF MS" mode with collision energy $10 \mathrm{eV}$, declustering potential $100 \mathrm{eV}$, and resolution more than 30,000 full-width half-maximum. Samples with the analyte concentration $5 \mu \mathrm{mol} / \mathrm{L}$ were prepared by dissolving the test compounds in a mixture of methanol (HPLC-UV Grade, LabScan) and water (LC-MS Grade, Panreac) in 1:1 ratio [22]. HPLC-MS analysis was performed using Agilent Zorbax Eclipse Plus C18 column $(2.1 \times 100 \mathrm{~mm}$, particle size $3.5 \mu \mathrm{m})$ with the flow rate of mobile phase $400 \mu \mathrm{L} / \mathrm{min}$. The HPLC purity of compounds $\mathbf{4 a}, \mathbf{b}$ was $>98 \%$.

Synthesis and analytical parameters of compounds $\mathbf{2 a}, \mathbf{b}$ and $3 \mathbf{a}$ have been described in our previous paper [23]. Fluconazole has been purchased from Sigma-Aldrich (USA)-SKU-Pack Size PHR1160-1G.

6-(Bromomethyl)-8-methyl-2-propyl-4H-[1,3]dioxino[4,5c]pyridin-5-yl)methanol (3b). To a solution of compound 
2b $(0.94 \mathrm{~g}, 3.71 \mathrm{mmol})$ in $100 \mathrm{ml}$ of dichloromethane were added triphenylphosphine $(0.93 \mathrm{~g}, 3.54 \mathrm{mmol})$ and then portionwise NBS $(0.63 \mathrm{~g}, 3.54 \mathrm{mmol})$, and the reaction mixture was stirred at room temperature for $0.5 \mathrm{~h}$. Then the reaction mixture was concentrated under vacuum and purified by column chromatography (petroleum ether/diethyl ether $=1: 4)$. Yield $50.9 \%(0.57 \mathrm{~g})$; white solid; mp $118-120^{\circ} \mathrm{C} ;{ }^{1} \mathrm{H}$ NMR $\left(\mathrm{CDCl}_{3}\right): \delta 0.99(\mathrm{t}, 3 \mathrm{H}, 3 \mathrm{JHH}=$ $\left.7.4 \mathrm{~Hz}, \mathrm{CH}_{2} \mathrm{CH}_{2} \mathrm{CH}_{3}\right), 1.50-1.59\left(\mathrm{~m}, 2 \mathrm{H}, \mathrm{CH}_{2} \mathrm{CH}_{2} \mathrm{CH}_{3}\right)$, 1.77-1.90 (m, $\left.2 \mathrm{H}, \mathrm{CH}_{2} \mathrm{CH}_{2} \mathrm{CH}_{3}\right), 2.36$ (s, $3 \mathrm{H}, \mathrm{CH}_{3} \mathrm{Pyr}$ ), 4.59, $4.63\left(\mathrm{AB}\right.$ system, $2 \mathrm{H},{ }^{2} \mathrm{JHH}=-10.0 \mathrm{~Hz}, \mathrm{CH}_{2}$ ), 4.59, $4.67\left(\mathrm{AB}\right.$ system, $\left.2 \mathrm{H},{ }^{2} \mathrm{JHH}=-12.8 \mathrm{~Hz}, \mathrm{CH}_{2}\right), 4.98(\mathrm{t}, 1 \mathrm{H}$, $\left.{ }^{3} \mathrm{JHH}=5.2 \mathrm{~Hz}, \mathrm{CH}\right), 5.01\left(\mathrm{~s}, 2 \mathrm{H}, \mathrm{CH}_{2}\right) \cdot{ }^{13} \mathrm{C} \mathrm{NMR}\left(\mathrm{CDCl}_{3}\right)$ : $\delta 13.99$ (s, $\mathrm{CH}_{2} \mathrm{CH}_{2} \mathrm{CH}_{3}$ ), 17.02 (s, $\left.\mathrm{CH}_{2} \mathrm{CH}_{2} \mathrm{CH}_{3}\right), 18.16$ (s, $\mathrm{CH}_{3} \mathrm{Pyr}$ ), 32.38 (s, $\mathrm{CH}_{2} \mathrm{CH}_{2} \mathrm{CH}_{3}$ ), 36.26 (s, $\left.\mathrm{CH}_{2} \mathrm{Br}\right), 57.71$ (s, $\left.\mathrm{CH}_{2}\right), 64.61\left(\mathrm{~s}, \mathrm{CH}_{2}\right), 99.95$ (s, CH), 128.67 (s, CPyr), 129.28 (s, CPyr), 145.18 (s, CPyr), 147.06 (s, CPyr), 148.26 (s, CPyr). HRMS-ESI: found $[\mathrm{M}+\mathrm{H}]^{+} 316.0543, \mathrm{C}_{13} \mathrm{H}_{19} \mathrm{BrNO}_{3}$, calculated $[\mathrm{M}+\mathrm{H}]^{+} 316.0543$.

1,1'-(2-(2,4-Difluorophenyl)-2-hydroxypropane-1,3-diyl)bis(4((5-(hydroxymethyl)-2,2,8-trimethyl-4H-[1,3]dioxino[4,5c]pyridin-6-yl)methyl)-1H-1,2,4-triazol-4-ium) Bromide (4a). Compound 3a $(1.5 \mathrm{~g}, 4.96 \mathrm{mmol})$ and fluconazole $(0.76 \mathrm{~g}$, $2.48 \mathrm{mmol}$ ) were dissolved in acetonitrile $(50 \mathrm{~mL})$, and the reaction mixture was stirred at $70^{\circ} \mathrm{C}$ for 1 week. Then the solvent was removed in vacuo, and the residue was dissolved in ethanol $(5 \mathrm{~mL})$. Diethyl ether $(30 \mathrm{~mL})$ was added, and the formed precipitate was collected by filtration. The product was purified by column chromatography on C18-reversed phase silica gel with gradient elution (isopropanol/water, 0-35\%). Yield: $47 \%$ (1.06 g); white solid; $\mathrm{mp} 147^{\circ} \mathrm{C}$ (decomp.); ${ }^{1} \mathrm{H}$ NMR (DMSO-d $\mathrm{d}_{6}$ ): $\delta 1.49\left(\mathrm{~s}, 12 \mathrm{H}, 4 \mathrm{CH}_{3}\right), 2.22(\mathrm{~s}, 6 \mathrm{H}$, $2 \mathrm{CH}_{3} \mathrm{Pyr}$ ), 4.43-4.50 (br m, $\left.4 \mathrm{H}, 2 \mathrm{CH}_{2} \mathrm{OH}\right), 4.99$ (s, $4 \mathrm{H}$, $2 \mathrm{CH}_{2}$ ), 5.06 (br s, $4 \mathrm{H}, 2 \mathrm{CH}_{2}$ ), $5.20-5.31\left(\right.$ br m, $2 \mathrm{H}, 2 \mathrm{CH}_{2} \mathrm{OH}$ ), 5.67 (br s, $4 \mathrm{H}, 2 \mathrm{CH}_{2}$ ), 6.81-6.85 (m, $\left.1 \mathrm{H}, \mathrm{CHAr}\right), 7.05(\mathrm{~d}, 1 \mathrm{H}$, $\left.{ }^{5} \mathrm{JHF}=1.7 \mathrm{~Hz}, \mathrm{OH}\right), 7.11-7.17(\mathrm{~m}, 1 \mathrm{H}, \mathrm{CHAr}), 7.29-7.35(\mathrm{~m}$, $1 \mathrm{H}, \mathrm{CHAr}$ ), 9.10 (br s, $1 \mathrm{H}, \mathrm{CHAr}$ ), 9.11 (br s, $1 \mathrm{H}, \mathrm{CHAr}$ ), 10.13-10.15 (m, 2H, 2CHAr). ${ }^{13} \mathrm{C}$ NMR (DMSO-d $\mathrm{d}_{6}$ ): $\delta 18.29$ (s, $\left.\mathrm{CH}_{3} \mathrm{Pyr}\right), 24.43\left(\mathrm{~s}, \mathrm{CH}_{3}\right), 24.47\left(\mathrm{~s}, \mathrm{CH}_{3}\right), 48.89$ (s, $\left.\mathrm{CH}_{2}\right)$, $55.06\left(\mathrm{~s}, \mathrm{CH}_{2}\right), 56.98\left(\mathrm{~s}, \mathrm{CH}_{2}\right), 58.45\left(\mathrm{~s}, \mathrm{CH}_{2}\right), 72.84(\mathrm{~d}$, $\left.{ }^{3} \mathrm{JCF}=3.9 \mathrm{~Hz}, \mathrm{C}-\mathrm{OH}\right), 99.57\left(\mathrm{~s}, \mathrm{C}\left(\mathrm{CH}_{3}\right)_{2}\right), 104.42\left(\mathrm{dd},{ }^{2} \mathrm{JCF}\right.$ $\left.=26.6 \mathrm{~Hz},{ }^{2} \mathrm{JCF}=26.8 \mathrm{~Hz}, \mathrm{CAr}\right), 111.36\left(\mathrm{~d},{ }^{2} \mathrm{JCF}=21.1 \mathrm{~Hz}\right.$, CAr), $121.16\left(\mathrm{dd},{ }^{2} \mathrm{JCF}=12.8 \mathrm{~Hz},{ }^{4} \mathrm{JCF}=3.1 \mathrm{~Hz}, \mathrm{CAr}\right), 126.64$ (s, CAr), 128.47 (s, CAr), $129.76\left(\mathrm{dd},{ }^{3} \mathrm{JCF}=8.6 \mathrm{~Hz},{ }^{3} \mathrm{JCF}=\right.$ $4.2 \mathrm{~Hz}, \mathrm{CAr}$ ), 140.33 (s, CAr), 144.47 (s, CAr), 145.04 (s, CAr), 145.26 (s, CAr), $159.09\left(\mathrm{dd},{ }^{1} \mathrm{JCF}=248.2 \mathrm{~Hz},{ }^{3} \mathrm{JCF}=12.4 \mathrm{~Hz}\right.$, CAr), $162.55\left(\mathrm{dd},{ }^{1} \mathrm{JCF}=248.0 \mathrm{~Hz},{ }^{3} \mathrm{JCF}=12.7 \mathrm{~Hz}, \mathrm{CAr}\right)$. HRMS-ESI: found $[\mathrm{M}-2 \mathrm{Br}]^{2+} 375.1644, \mathrm{C}_{37} \mathrm{H}_{44} \mathrm{~F}_{2} \mathrm{~N}_{8} \mathrm{O}_{7}$, calculated $[\mathrm{M}-2 \mathrm{Br}]^{2+} 375.1645$.

1,1'-(2-(2,4-Difluorophenyl)-2-hydroxypropane-1,3-diyl)bis(4((5-(hydroxymethyl)-8-methyl-2-propyl-4H-[1,3]dioxino[4,5clpyridin-6-yl)methyl)-1H-1,2,4-triazol-4-ium) Bromide (4b). Compound $3 \mathbf{b}(0.54 \mathrm{~g}, 1.71 \mathrm{mmol})$ and fluconazole $(0.20 \mathrm{~g}$, $0.65 \mathrm{mmol}$ ) were dissolved in acetonitrile $(50 \mathrm{~mL})$, and the reaction mixture was stirred at $70^{\circ} \mathrm{C}$ for 1 week. The solvent was removed in vacuo, and then a diethyl ether/water mixture $(5: 3,40 \mathrm{~mL})$ was added to the residue. The aqueous and organic phases were separated, and the aqueous layer was concentrated to a volume of $1 \mathrm{~mL}$. Ethanol $(1 \mathrm{~mL})$ was added, and the dissolved product was purified by column chromatography on C18-reversed phase silica gel with gradient elution (isopropanol/water, 0-30\%). Yield: $64 \%$ (0.39 g); yellow solid; mp $120^{\circ} \mathrm{C}$ (decomp.); ${ }^{1} \mathrm{H}$ NMR $\left(\mathrm{CDCl}_{3}\right): \delta 0.97\left(\mathrm{t}, 12 \mathrm{H},{ }^{3} \mathrm{JHH}=7.3 \mathrm{~Hz}, 4 \mathrm{CH}_{2} \mathrm{CH}_{2} \mathrm{CH}_{3}\right)$, 1.47-1.56 (m, $\left.8 \mathrm{H}, 4 \mathrm{CH}_{2} \mathrm{CH}_{2} \mathrm{CH}_{3}\right), \quad 1.73-1.86(\mathrm{~m}, 8 \mathrm{H}$, $\left.4 \mathrm{CH}_{2} \mathrm{CH}_{2} \mathrm{CH}_{3}\right), 2.28\left(\mathrm{~s}, 6 \mathrm{H}, 2 \mathrm{CH}_{3} \mathrm{Pyr}\right), 2.28(\mathrm{~s}, 6 \mathrm{H}$, $\left.2 \mathrm{CH}_{3} \mathrm{Pyr}\right), 4.53,4.58\left(\mathrm{AB}\right.$ system, $8 \mathrm{H},{ }^{2} \mathrm{JHH}=-12.0 \mathrm{~Hz}$, $\left.4 \mathrm{CH}_{2}\right), 4.81-5.01\left(\mathrm{~m}, 16 \mathrm{H}, 4 \mathrm{CH}_{2}, 4 \mathrm{CH}_{2}-\mathrm{OH}, 4 \mathrm{CH}\right), 5.04,5.14$ $\left(\mathrm{AB}\right.$ system, $\left.8 \mathrm{H},{ }^{2} \mathrm{JHH}=-14.0 \mathrm{~Hz}, 4 \mathrm{CH}_{2}\right), 5.67-5.82(\mathrm{~m}, 4 \mathrm{H}$, $4 \mathrm{CH}_{2}-\mathrm{OH}$ ), 6.58-6.69 (br m, 2H, 2CHAr), 6.78-6.83 (m, 2H, 2CHAr), 6.86 (br s, $2 \mathrm{H}, 2 \mathrm{OH}$ ), 7.27-7.33 (m, 2H, 2CHAr), 8.66 (s, 2H, 2CHAr), 8.67 (s, 2H, 2CHAr), 10.55 (br s, $4 \mathrm{H}$, 4CHAr). ${ }^{13} \mathrm{C}$ NMR $\left(\mathrm{CDCl}_{3}\right): \delta 14.02\left(\mathrm{~s}, \mathrm{CH}_{2} \mathrm{CH}_{2} \mathrm{CH}_{3}\right), 17.04$ (s, $\mathrm{CH}_{2} \mathrm{CH}_{2} \mathrm{CH}_{3}$ ), 18.45 (s, $\mathrm{CH}_{3} \mathrm{Pyr}$ ), $36.24\left(\mathrm{~s}, \mathrm{CH}_{2} \mathrm{CH}_{2} \mathrm{CH}_{3}\right.$ ), $50.60\left(\mathrm{~s}, \mathrm{CH}_{2}\right), 56.01\left(\mathrm{~s}, \mathrm{CH}_{2}\right), 57.30\left(\mathrm{~s}, \mathrm{CH}_{2}\right), 57.33\left(\mathrm{~s}, \mathrm{CH}_{2}\right)$, $64.69\left(\mathrm{~s}, \mathrm{CH}_{2}\right), 73.34\left(\mathrm{~d},{ }^{3} \mathrm{JCF}=2.3 \mathrm{~Hz}, \mathrm{C}-\mathrm{OH}\right), 99.81(\mathrm{~s}$, $\mathrm{CH}), 104.37\left(\mathrm{dd},{ }^{2} \mathrm{JCF}=-26.7 \mathrm{~Hz},{ }^{2} \mathrm{JCF}=-27.1 \mathrm{~Hz}, \mathrm{CAr}\right.$ ), $112.12\left(\mathrm{dd},{ }^{2} \mathrm{JCF}=-20.3 \mathrm{~Hz},{ }^{4} \mathrm{JCF}=-4.5 \mathrm{~Hz}, \mathrm{CAr}\right), 120.34$ $\left(\mathrm{dd},{ }^{2} \mathrm{JCF}=-9.4 \mathrm{~Hz},{ }^{4} \mathrm{JCF}=-3.5 \mathrm{~Hz}, \mathrm{CAr}\right), 128.46(\mathrm{~s}, \mathrm{CAr})$, $128.98(\mathrm{~s}, \mathrm{CAr}), 130.39\left(\mathrm{dd},{ }^{3} \mathrm{JCF}=9.7 \mathrm{~Hz},{ }^{3} \mathrm{JCF}=5.1 \mathrm{~Hz}\right.$, CAr), 140.40 (s, CAr), 140.44 (s, CAr), 144.15 (s, CAr), 144.24 (s, CAr), 144.52 (s, CAr), 144.55 (s, CAr), 147.18 (s, CAr), 147.20 (s, CAr), 148.09 (s, CAr), 148.11 (s, CAr), 159.23 $\left(\mathrm{dd},{ }^{1} \mathrm{JCF}=248.0 \mathrm{~Hz},{ }^{3} \mathrm{JCF}=12.8 \mathrm{~Hz}, \mathrm{CAr}\right), 163.41(\mathrm{dd}$, ${ }^{1} \mathrm{JCF}=251.6 \mathrm{~Hz},{ }^{3} \mathrm{JCF}=13.2 \mathrm{~Hz}, \mathrm{CAr}$ ). HRMS-ESI: found $[\mathrm{M}-2 \mathrm{Br}]^{2+} 389.1801, \mathrm{C}_{39} \mathrm{H}_{48} \mathrm{~F}_{2} \mathrm{~N}_{8} \mathrm{O}_{7}$, calculated $[\mathrm{M}-2 \mathrm{Br}]^{2+}$ 389.1801 .

\subsection{In Vitro Studies}

2.2.1. Antimycotic Activity. Antimycotic activity of the obtained compounds $\mathbf{4 a , b}$ and the reference drugs, fluconazole and terbinafine (terbinafine was purchased from Sigma-Aldrich (USA)-SKU-Pack Size PHR1298-1G), was evaluated on several fungal strains causing cutaneous and systemic mycoses. The following strains were obtained from a collection of clinical isolates of the Kazan Institute of Microbiology and Epidemiology (Kazan, Russia): Candida albicans K-1663 (clinical strain isolated from pharynx mucosa), Aspergillus fumigatus 1320-13 (clinical strain isolated from nasal cavity), and Trichophyton rubrum K-1 (clinical strain isolated from skin). Rhizopus nigricans 600 was taken from the All-Russian collection of microorganisms (etalon strain).

For the inoculum preparation, the pure 2- and 5-day cultures of yeasts and filamentous fungi, respectively, grown on Sabouraud dense nutrient medium, were used. Yeast cultures of C. albicans were prepared by flushing the culture from the surface of the solid agar medium. Cultures of mycelial fungi T. rubrum, $R$. nigricans, A. fumigatus were preground in a mortar. A suspension of microorganisms was prepared in a sterile isotonic solution of sodium chloride. The cell concentrations were $(1 \div 5) \times 10^{3}$ for yeast fungi and $(0.4$ $\div 5) \times 10^{4}$ for mycelial fungi. 
The study of the antifungal activity of substances in vitro was carried out in a liquid nutrient medium (glucose Sabouraud broth) in biological test tubes by 2 -fold serial dilutions approach. Test compounds were prepared at concentrations ranging from 400 to $0.38 \mu \mathrm{g} / \mathrm{mL}$. A test tube in the absence of test compounds served as a control. To each tube, $50 \mu \mathrm{L}$ of inoculum was added. The tubes were incubated for 2-7 days at $30^{\circ} \mathrm{C}$. To the end of this period, the results were assessed by visual analysis of optical density of the medium. The following MIC endpoints were determined: 0 $=$ clear solution, no growth; 1 = weak growth ( $25 \%$ control); 2 = significant inhibition of growth (50\% control); $3=$ insignificant growth inhibition ( $75 \%$ control); $4=$ no growth inhibition. All experiments were carried out in duplicate.

2.2.2. Activity against the Clinical Strains of C. albicans in Biofilms. The ability of fluconazole and $\mathbf{4 b}$ to inhibit the biofilm formation was evaluated on the following C. albicans strains: C. albicans K-1663 (isolated from pharynx mucosa); C. albicans $\mathrm{K}-4467$ (isolated from skin). These strains were obtained from a collection of clinical isolates of the Kazan Institute of Microbiology and Epidemiology (Kazan, Russia).

To detect the inhibitory effect of the studied compounds on C. albicans biofilm formation, a semiquantitative determination of biofilm formation was performed in microtiter plates as described earlier [24, 25]. The cell culture seeded in Sabouraud liquid medium was incubated in orbital shaker $(180 \mathrm{rpm})$ for $24 \mathrm{~h}$ at $30^{\circ} \mathrm{C}$. Then the culture was washed twice with a sterile phosphate buffer and resuspended in Sabouraud liquid medium to achieve the final cell density 1.0 $\times 10^{6}$ cells $/ \mathrm{mL}$. A $100 \mu$ L cell suspension was added to 96 -well flat-bottom polystyrene microsheets (Corning/Costar, USA) and incubated for 24 hours at $37^{\circ} \mathrm{C}$. After biofilm formation, the plates were washed three times with sterile phosphate buffer and the biofilm formed at this point was taken as the biofilm level before the treatment. Then $125 \mu \mathrm{L}$ aliquots of test compounds were added in various concentrations, and the plates were incubated for 48 hours. After incubation, the plates were washed three times with sterile phosphate buffer, dried for 30 minutes at $37^{\circ} \mathrm{C}$, and stained with $125 \mu \mathrm{L}$ of a $1 \%$ aqueous solution of crystal violet. After staining for 20 minutes at $37^{\circ} \mathrm{C}$, the plates were washed, $125 \mu \mathrm{L}$ of $95 \%$ ethanol was added to dissolve the stained dye, and the optical density at $620 \mathrm{~nm}$ was measured using a spectrophotometer to assess the amount of adhered and stained cells. All experiments were carried out in triplicate.

2.2.3. Antibacterial Activity. Antibacterial activity of compounds $\mathbf{4 a , b}$ was evaluated on a number of Gram-positive (Staphylococcus aureus ATCC ${ }^{\circledR} 29213^{\mathrm{TM}}$, Bacillus subtilis 168 , Staphylococcus epidermidis (clinical isolate), and Micrococcus luteus (clinical isolate)) and Gram-negative (Escherichia coli ATCC ${ }^{\circledR} 25922^{\mathrm{TM}}$, Pseudomonas aeruginosa ATCC ${ }^{\circledR} 27853^{\mathrm{TM}}$, Salmonella typhimurium TA100, K. pneumoniae (clinical isolate)) bacteria. Clinical isolates of Staphylococcus epidermidis, Micrococcus luteus, and Klebsiella pneumoniae were obtained from the Kazan Institute of Epidemiology and Microbiology (Kazan, Russia).
MICs were determined by using the broth microdilution method in 96-well plates (Eppendorf) according to the EUCAST rules for antimicrobial susceptibility testing [26] with some modifications. Briefly, the $10^{8}$ cells $/ \mathrm{ml}$ bacterial suspensions were subsequently diluted 100-fold with TSB broth to obtain a $1 \times 10^{6}$ cells $/ \mathrm{mL}$ suspension, and various concentrations of antimicrobials were added in microwell plates up to final concentrations of $0.5-64 \mu \mathrm{g} / \mathrm{mL}$. The cultures were incubated at $37^{\circ} \mathrm{C}$ for $24 \mathrm{~h}$. The minimum inhibitory concentration was defined as the lowest concentration of compound at which no visible growth could be seen after $24 \mathrm{~h}$ of cultivation at $37^{\circ} \mathrm{C}$. To determine minimum bactericidal concentration, $5 \mu \mathrm{L}$ of culture liquid from wells without visible growth was plated on solid LB medium and incubated for $24 \mathrm{~h}$ at $37^{\circ} \mathrm{C}$. MBC was assumed at antimicrobials concentrations where no viable planktonic cells were observed. All experiments were performed in triplicate.

For investigation of the antimicrobial mechanism of compound $\mathbf{4 b}$, MICs were also determined in the presence of $0.1 \mathrm{M} \mathrm{CaCl}_{2}$ in nutrient broth on six Gram-positive and Gram-negative strains from the same bacterial panel.

2.2.4. Activity against Bacterial Biofilms. Bacterial biofilms were grown under static conditions in BM for $72 \mathrm{~h}$ at $37^{\circ} \mathrm{C}$. Subsequently, the supernatants were carefully removed and the biofilms were washed with fresh sterile BM broth. Aliquots $(500 \mu \mathrm{L})$ of antimicrobials solutions with concentrations between 1 and $16 \mathrm{MBC}$ in fresh $\mathrm{BM}$ buffer were added to the wells, and cultivation was continued for 24 hours at $37^{\circ} \mathrm{C}$. To evaluate the viability of biofilm-embedded cells, the wells were washed several times with sterile phosphate-buffered saline (PBS) to remove nonadherent and detached cells. The washed biofilms were suspended in PBS by scratching the well bottoms with following treatment in a sonicator bath for $2 \mathrm{~min}$ at $20 \mathrm{kHz}$ to favor the disintegration of bacterial clumps, and viable cells were counted by a drop plate method with minor modifications $[27,28]$. The serial 10 fold dilutions of each well were prepared and a $5 \mu \mathrm{L}$ aliquot of the suspension was dropped onto LB agar plates. CFUs were counted from those drops containing 5-10 colonies and presented as CFU per $\mathrm{mL}$.

Experiments were carried out in biological triplicates (i.e., newly prepared cultures and medium) with 3 independent repeats in each one. Since the drop plate assay results were assessed from 10-fold dilutions, where the number of colonies was typically countable only in the two latter dilutions, to assess the statistical significance, we compared $10 \log _{10}(c)$, where $c$ is the obtained cell number, using Pearson's chisquared homogeneity test.

2.2.5. Cytotoxic Activity. The human fibroblast cells (HFC) or embryonic kidney 293 cells (HEK-293) were cultured in $\alpha$-MEM supplemented with $10 \% \mathrm{FBS}, 2 \mathrm{mM}$ L-glutamine, $100 \mu \mathrm{g} / \mathrm{mL}$ penicillin, and $100 \mathrm{U} / \mathrm{mL}$ streptomycin. The cells were seeded in 96-well plates at the density of 1000 cells per well and then allowed to attach overnight. Cells were cultured in the presence of the tested compound's solutions 
$(0.15-1 \mathrm{mg} / \mathrm{mL})$ for $72 \mathrm{~h}$ at $37^{\circ} \mathrm{C}$ and $5 \% \mathrm{CO}_{2}$. After incubation, the medium with the tested compound's solutions was removed by aspiration and replaced with $80 \mu \mathrm{L}$ of fresh $\alpha$ MEM medium. MTT solution ( $20 \mu \mathrm{L}$ of $5 \mathrm{mg} / \mathrm{mL}$ MTT) was added to each well, and the plates were incubated for 3.5 hours at $37^{\circ} \mathrm{C}$ in culture hood. After the incubation period, the medium with MTT solution was removed, and $100 \mu \mathrm{L}$ of DMSO was added to each well to dissolve the resulting formazan crystals. The colored product of MTT reduction by viable cells was detected on Infinite 200 PRO analyzer at $530 \mathrm{~nm}$. All measurements were performed in triplicate.

2.2.6. Genotoxicity. The SOS-chromotest was performed by using the Salmonella typhimurium TA1535/pSK1002. Briefly, aliquots of $0.5 \mathrm{~mL}$ of an overnight culture of the tester strains were diluted in $5 \mathrm{~mL}$ of $\mathrm{LB}$ medium and then incubated with rigorous agitation in presence of the ficin substances. Mitomycin C (Sigma) at concentration of $1 \mu \mathrm{g} / \mathrm{mL}$ was used as a positive control in SOS-chromotest. After $4 \mathrm{~h}$ of incubation, the cell density (A600) and the $\beta$-galactosidase activity were measured by Miller's protocol [29] with modifications [30]. Cells were harvested from $0.5-1.5 \mathrm{ml}$ of culture liquid and resuspended in $800 \mu \mathrm{l}$ of Z-buffer $\left(60 \mathrm{mM} \mathrm{Na}_{2} \mathrm{HPO}_{4} \times\right.$ $7 \mathrm{H}_{2} \mathrm{O}, 40 \mathrm{mM} \mathrm{NaH} \mathrm{PO}_{4} \times \mathrm{H}_{2} \mathrm{O}, 10 \mathrm{mM} \mathrm{KCl}$, and $1 \mathrm{mM}$ $\mathrm{MgSO}_{4} \times 7 \mathrm{H}_{2} \mathrm{O}(\mathrm{pH}$ 7.0)) containing additionally $0.005 \%$ cetyl trimethylammonium bromide (CTAB) and $50 \mathrm{mM} \beta$ mercaptoethanol was added. After preincubation at $30^{\circ} \mathrm{C}$ for $5 \mathrm{~min}$, the reaction was started by adding $200 \mu \mathrm{L}$ of $4 \mathrm{mg} / \mathrm{mL}$ $o$-nitrophenyl- $\beta$-D-galactopyranoside in Z-buffer. When the yellow color appeared, the reaction was stopped by $500 \mu \mathrm{L}$ of $1 \mathrm{M} \mathrm{Na}_{2} \mathrm{CO}_{3}$. For the blank solution, the $\mathrm{Na}_{2} \mathrm{CO}_{3}$ was added prior the incubation. The $\beta$-galactosidase activity was measured at A420 nm. To calculate the Miller units, we used the following formula: [A420/(A600 of 1:10 dilution of cells $\times$ time of incubation) $] \times 1000$.

S. typhimurium strains TA98, TA100, TA102, TA1535, and TA1537 were used for the Ames test. Briefly, S. typhimurium strains [31] were grown overnight in $5 \mathrm{~mL}$ of LB medium and diluted 4-times by prewarmed LB, and then incubation was continued for $2 \mathrm{~h}$. Cells were harvested, washed once by $1 \mathrm{x}$ salt base solution (sodium citrate $\times 3 \mathrm{H}_{2} \mathrm{O}-0.5 \mathrm{~g} / \mathrm{L}$; $\mathrm{K}_{2} \mathrm{HPO}_{3} \times 3 \mathrm{H}_{2} \mathrm{O}-14 \mathrm{~g} / \mathrm{L} ; \mathrm{KH}_{2} \mathrm{PO}_{3}-6 \mathrm{~g} / \mathrm{L} ;\left(\mathrm{NH}_{4}\right)_{2} \mathrm{SO}_{4}$ $-1 \mathrm{~g} / \mathrm{L} ; \mathrm{MgSO}_{4} \times 7 \mathrm{H}_{2} \mathrm{O}-0.5 \mathrm{~g} / \mathrm{L}$ ) and resuspended in $6 \mathrm{~mL}$ of $1 \mathrm{x}$ salt base. About $100 \mu \mathrm{L}$ of bacterial suspension was mixed with top agar $(0.5 \%$ agar, $0.5 \% \mathrm{NaCl}, 5 \mathrm{mM} \mathrm{L}$ histidine, $5 \mathrm{mM}$ biotin, $\mathrm{pH} 7.4,42^{\circ} \mathrm{C}$ ) in a final volume of $3 \mathrm{~mL}$ and with the substance to be tested. Each mixture was then seeded onto the minimal agar plates $(1.5 \%$ agar in the $1 \mathrm{x}$ salt base supplemented with $0.5 \%$ glucose and ampicillin $10 \mu \mathrm{g} / \mathrm{mL}$ ). Then the plates were incubated at $37^{\circ} \mathrm{C}$ for 72 hours and colonies were counted. Sodium azide was used as a positive control for S. typhimurium TA100 $(5 \mu \mathrm{g} /$ plate $)$ and S. typhimurium TA102 $(20 \mu \mathrm{g} /$ plate $)$ and TA1535 ( $5 \mu \mathrm{g} /$ plate); 9 -aminoacridine was used as a positive control for S. typhimurium TA1537 (5 $\mu \mathrm{g} /$ plate); 4-nitro-ophenylenediamine was used as a positive control for $S$. typhimurium TA98 (2.5 $\mu \mathrm{g} /$ plate).

\section{Results and Discussion}

\subsection{Results}

3.1.1. Synthesis. The synthetic way to the studied compounds is shown in Scheme 1. The key intermediates $\mathbf{2 a} \mathbf{a}, \mathbf{b}$ have been obtained from initial pyridoxine hydrochloride 1 according to procedure described previously [23]. Reaction of 2a,b with triphenylphosphine and $\mathrm{N}$-bromosuccinimide in dichloromethane gave the corresponding bromides $\mathbf{3 a}, \mathbf{b}$ as the main products. Reaction of $\mathbf{3 a}, \mathbf{b}$ with fluconazole in acetonitrile led to the target compounds $\mathbf{4 a}, \mathbf{b}$. The synthesis is convenient and well reproducible at a laboratory scale. Compounds $\mathbf{4 a , b}$ were purified using flash chromatography on C18 silica gel. Synthesis and analytical parameters of compounds $\mathbf{2 a} \mathbf{a}, \mathbf{b}$ and $\mathbf{3} \mathbf{a}$ have been described previously [23], while compounds $\mathbf{3 b}$ and $\mathbf{4 a , b}$ are described in this work for the first time.

3.1.2. Antimycotic Activity. Antimycotic activity of compounds $\mathbf{4 a}, \mathbf{b}$ was studied on a panel of fungal pathogens (Table 1) in comparison with fluconazole and terbinafine as reference drugs. Compound $\mathbf{4 b}$ exhibited a pronounced antimycotic activity against all the tested fungi with minimum inhibitory concentrations (MIC) 1.5, 6.25, 3.12, and $3.12 \mu \mathrm{g} / \mathrm{mL}$ against C. albicans No. 1663, T. rubrum, A. fumigatus, and $R$. nigricans, respectively, which were 15-30fold lower than those of fluconazole and similar with those of terbinafine. In the case of $A$. fumigatus, $\mathbf{4 b}$ exhibited higher activity than terbinafine (MICs $3.12 \mu \mathrm{g} / \mathrm{mL}$ and $12.5 \mu \mathrm{g} / \mathrm{mL}$, respectively). Compound $\mathbf{4 a}$ demonstrated a moderate fungicidal effect against the clinical strain of C. albicans (MIC $25 \mu \mathrm{g} / \mathrm{mL}$ ), but was less active against the mycelial fungi with MICs of $200 \mu \mathrm{g} / \mathrm{mL}$. Interestingly, the direct analog of the obtained compounds, fluconazole, was inactive in this experiment against the investigated mycelial fungi and only moderately active against the clinical strain of $C$. albicans (MIC $50 \mu \mathrm{g} / \mathrm{mL}$ ).

3.1.3. Prevention of C. albicans Biofilm Growth. Formation of biofilms is one of the important mechanisms of C. albicans survival. We tested whether fluconazole and the leading compound $\mathbf{4 b}$ are able to inhibit the biofilm formation of clinical isolates of C. albicans in vitro (Figure 1). The 24-hourold biofilm of C. albicans was prepared in 96-well plates. In control wells, the biofilm was stained with crystal violet and taken as biofilm level before treatment (green line). In experimental wells, various concentrations of fluconazole and $\mathbf{4 b}$ in Sabouraud broth were then added. After $48 \mathrm{~h}$ of incubation the biofilms were evaluated using a crystal violet assay.

Figure 1 demonstrates that fluconazole inhibits the biofilm biomass growth only at concentrations higher than $200 \mu \mathrm{g} / \mathrm{mL}$. At lower concentrations it increases the biofilm formation by $C$. albicans clinical isolates, leading to 2-2.5fold increase of total biofilm mass in comparison with untreated control; this effect is maximally pronounced at concentrations between 25 and $50 \mu \mathrm{g} / \mathrm{mL}$. The effect of 
<smiles>[R]C1([R])OCc2c(CO)c(CO)nc(C)c2O1</smiles><smiles>[R]C1([R])OCc2c(CO)c(CBr)nc(C)c2O1</smiles>

2a, $\mathrm{R}^{1}=\mathrm{R}^{2}=\mathrm{CH}_{3}[22]$

2b, $\mathrm{R}^{1}=\mathrm{H}, \mathrm{R}^{2}=\mathrm{C}_{3} \mathrm{H}_{7}[22]$<smiles>[R]C1([R])OCc2c(CO)c(C[N+](C)=CC)nc(C)c2O1</smiles>

3a, $\mathrm{R}^{1}=\mathrm{R}^{2}=\mathrm{CH}_{3}[22]$

3b, $\mathrm{R}^{1}=\mathrm{H}, \mathrm{R}^{2}=\mathrm{C}_{3} \mathrm{H}_{7}$

$$
\begin{aligned}
& \text { 4a, } \mathrm{R}^{1}=\mathrm{R}^{2}=\mathrm{CH}_{3} \\
& \text { 4b, } \mathrm{R}^{1}=\mathrm{H}, \mathrm{R}^{2}=\mathrm{C}_{3} \mathrm{H}_{7}
\end{aligned}
$$

Fluconazole

(0.38-0.5 equiv.)

$\mathrm{CH}_{3} \mathrm{CN}, 70^{\circ} \mathrm{C}$

SCHEME 1: Synthesis of compounds studied in this work.

\begin{tabular}{|c|c|c|c|c|c|c|c|c|c|c|c|c|}
\hline \multirow{2}{*}{ Compound } & \multirow{2}{*}{ Strains } & \multicolumn{11}{|c|}{$\mathrm{MIC}, \mu \mathrm{g} / \mathrm{mL}$} \\
\hline & & 400 & 200 & 100 & 50 & 25 & 12.5 & 6.25 & 3.12 & 1.5 & 0.75 & 0.38 \\
\hline \multirow{4}{*}{ Fluconazole } & C. albicans & 0 & 0 & 0 & 0 & 1 & 1 & 3 & 4 & 4 & 4 & 4 \\
\hline & T. rubrum & 2 & 4 & 4 & 4 & 4 & 4 & 4 & 4 & 4 & 4 & 4 \\
\hline & A. fumigatus & 3 & 4 & 4 & 4 & 4 & 4 & 4 & 4 & 4 & 4 & 4 \\
\hline & R. nigricans & 4 & 4 & 4 & 4 & 4 & 4 & 4 & 4 & 4 & 4 & 4 \\
\hline \multirow{4}{*}{ Terbinafine } & C. albicans & 0 & 0 & 0 & 0 & 0 & 0 & 0 & 0 & 0 & 0 & 1 \\
\hline & T. rubrum & 0 & 0 & 0 & 0 & 0 & 0 & 0 & 0 & 1 & 1 & 2 \\
\hline & A. fumigatus & 0 & 0 & 0 & 0 & 0 & 0 & 1 & 1 & 3 & 4 & 4 \\
\hline & R. nigricans & 0 & 0 & 0 & 0 & 0 & 0 & 0 & 1 & 1 & 4 & 4 \\
\hline \multirow{4}{*}{$4 a$} & C. albicans & 0 & 0 & 0 & 0 & 0 & 2 & 2 & 3 & 4 & 4 & 4 \\
\hline & T. rubrum & 0 & 0 & 4 & 4 & 4 & 4 & 4 & 4 & 4 & 4 & 4 \\
\hline & A. fumigatus & 0 & 0 & 4 & 4 & 4 & 4 & 4 & 4 & 4 & 4 & 4 \\
\hline & R. nigricans & 0 & 0 & 4 & 4 & 4 & 4 & 4 & 4 & 4 & 4 & 4 \\
\hline \multirow{4}{*}{$4 b$} & C. albicans & 0 & 0 & 0 & 0 & 0 & 0 & 0 & 0 & 0 & 4 & 4 \\
\hline & T. rubrum & 0 & 0 & 0 & 0 & 0 & 0 & 0 & 1 & 4 & 4 & 4 \\
\hline & A. fumigatus & 0 & 0 & 0 & 0 & 0 & 0 & 0 & 0 & 1 & 4 & 4 \\
\hline & R. nigricans & 0 & 0 & 0 & 0 & 0 & 0 & 0 & 0 & 1 & 2 & 4 \\
\hline
\end{tabular}

TABLE 1: Activity of compounds $\mathbf{4 a}, \mathbf{b}$ on a panel of fungal pathogens.

Note. 0 = clear solution, no growth; $1=$ weak growth $(25 \%$ of control); 2 = significant inhibition of growth $(50 \%$ of control); $3=$ insignificant growth inhibition (75\% of control); 4 = no growth inhibition (100\% of control). 


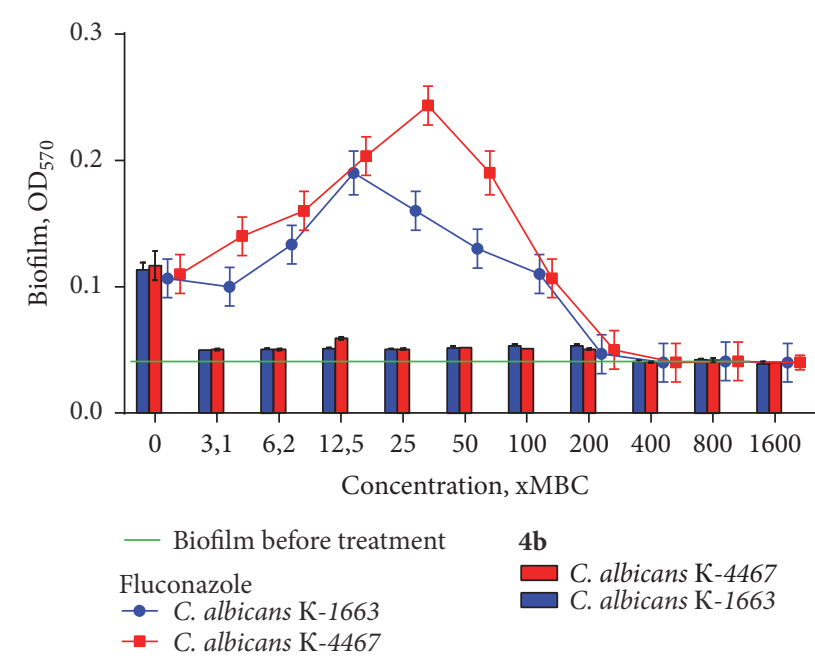

FIgURE 1: The effect of fluconazole and $\mathbf{4 b}$ on C. albicans biofilm formation. The 24-h biofilms (green line) were treated with $3.1-1600 \mu \mathrm{g} / \mathrm{mL}$ of fluconazole (lines) or $4 \mathbf{b}$ (bars) for $48 \mathrm{~h}$ and quantified with crystal violet assay. Data are present as averages from five independent experiments with standard deviations. C. albicans K-1663 isolated from pharynx mucosa (blue) and C. albicans K-4467 isolated from skin (red) were used.

escape of Candida from inhibition by antifungal agents at concentrations above the MIC (paradoxical or Eagle effect) was previously reported. Thus, a growth of some C. albicans strains in vitro [32, 33], in vivo [34], and in biofilms [35] was observed for caspofungin. It was also shown that fluconazole can induce the growth of planktonic C. krusei at sub-MICs [36]. Although the molecular mechanisms of such effects of antifungal agents remain largely unknown, it has been argued that the salvage pathways associated with changes in cell morphology and cell wall rearrangements [37] play a principal role.

In contrast to fluconazole, compound $\mathbf{4 b}$ effectively suppressed the biofilm growth even at minimal concentrations as compared to untreated sample (Figure 1). Of note, the treatment with fluconazole and $\mathbf{4 b}$ did not lead to destruction of preformed biofilm.

3.1.4. Antibacterial Activity. The antibacterial activity of compounds $\mathbf{4 a , b}$ was evaluated on various Gram-positive and Gram-negative bacteria. Table 2 shows MICs of compounds in comparison with the reference antifungal drugs (fluconazole and terbinafine) and antibacterial drugs (benzalkonium chloride and miramistin). Compound $\mathbf{4 b}$ demonstrated high antibacterial activity with MICs in the range of $0.5-32 \mu \mathrm{g} / \mathrm{mL}$ for all the studied pathogens. Its activity against the Grampositive strains in this test (MICs $0.5-8 \mu \mathrm{g} / \mathrm{mL}$ ) was comparable with that of the reference antibacterial drugs. At the same time, it was active against all the four Gram-negative strains (MICs $8-32 \mu \mathrm{g} / \mathrm{mL}$ ), while benzalkonium chloride was inactive against K. pneumoniae. Compound 4a showed a moderate activity against two Gram-positive strains (MIC $32 \mu \mathrm{g} / \mathrm{mL}$ ), while both antifungal drugs were inactive in this experiment. For all the studied strains, the MBC/MIC ratio of $\mathbf{4 b}$ was found to be 2-4 suggesting its biocidal properties.

Antibacterial activity of compound $\mathbf{4 b}$ has also been tested on six bacterial strains from the same panel of pathogens in the presence of $\mathrm{CaCl}_{2}$ [38]. The MIC values of $\mathbf{4 b}$ in the presence of $\mathrm{Ca}^{2+}$ ions were significantly increased for both Gram-positive and Gram-negative strains $\left(>64 \mu \mathrm{g} / \mathrm{mL}\right.$ as compared to $1-32 \mu \mathrm{g} / \mathrm{mL}$ under $\mathrm{Ca}^{2+}$-free conditions). This observation suggests that the cell wall damage could be associated with the $\mathrm{Ca}^{2+}$ removal and might represent the possible mechanisms of antibacterial action of $4 b$.

3.1.5. Activity against Bacterial Biofilms. Activity of $\mathbf{4 b}$ against the biofilm-embedded cells was evaluated on four common human resident Gram-positive (S. aureus, S. epidermidis) and Gram-negative (E. coli, P. aeruginosa) bacterial strains causing nosocomial infections and forming rigid biofilms on tissues and abiotic surfaces. Similar to C. albicans, the 24-h bacterial biofilms were established on 96-well plates, washed, and incubated with different concentrations of $\mathbf{4 b}$, miramistin, and benzalkonium chloride in BM broth for the next $24 \mathrm{~h}$. The untreated 24-hour-old biofilm was taken as biofilm level before the treatment. Then the wells were stained with crystal violet and quantified. All the antimicrobials insignificantly increased the biofilm mass at concentrations $(0.5-4) \times$ MBCs, while $(8-16) \times$ MBCs almost completely repressed the biofilm growth (Figure 2).

Since no biofilm eradication occurred at all concentrations of $\mathbf{4} \mathbf{b}$ tested, its antimicrobial activity against biofilmembedded cells was evaluated by counting of viable cells (colony-forming units, CFUs) inside the biofilm (Figure 3). The activity of $\mathbf{4 b}$ in these experiments was comparable with that of other ammonium quaternary salts like miramistin and benzalkonium chloride as judged with Pearson's chi-squared homogeneity test. Similar to reference antimicrobials, $\mathbf{4 b}$ was active against the biofilm-embedded staphylococci (Figures 3(a) and 3(b)) and E. coli (Figure 3(c)) reducing the CFUs amount by $2-3$ orders of magnitude at $16 \times \mathrm{MBC}$. By contrast, all compounds were almost inactive against $P$. aeruginosa even at $16 \times \mathrm{MBC}$ (Figure $3(\mathrm{~d})$ ).

3.1.6. Genotoxicity. In order to evaluate the genotoxicity of $\mathbf{4 b}$, the Ames test [31] was performed using five $S$. typhimurium TA98, TA100, TA102, TA1535, and TA1537 strains. The positive controls for each strain are described in the Methods section. The samples were taken in concentrations of $0.2,0.4,0.8$, and $1.6 \mu \mathrm{g} / \mathrm{mL}$ since higher concentrations were toxic for $S$. typhimurium. In all the studied strains, no increase in the number of revertant colonies was detected, as well as no dose-dependence was observed (Table 3), suggesting the absence of mutagenic potential of $4 b$.

Genotoxicity of compound $\mathbf{4 b}$ was also evaluated using SOS-chromotest in S. typhimurium TA1535/pSK1002 strain as previously described [39]. Mitomycin C was used as a positive 


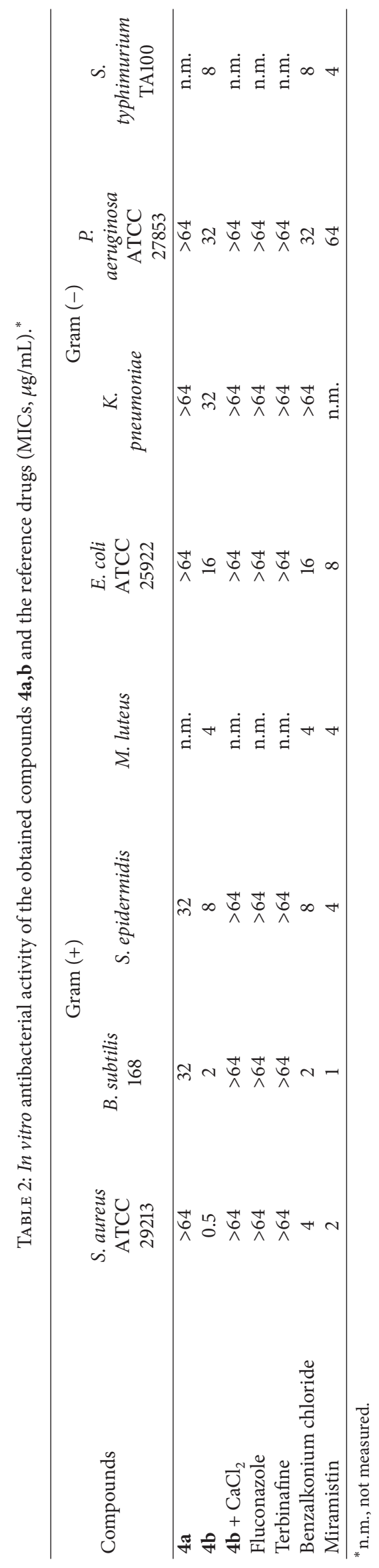



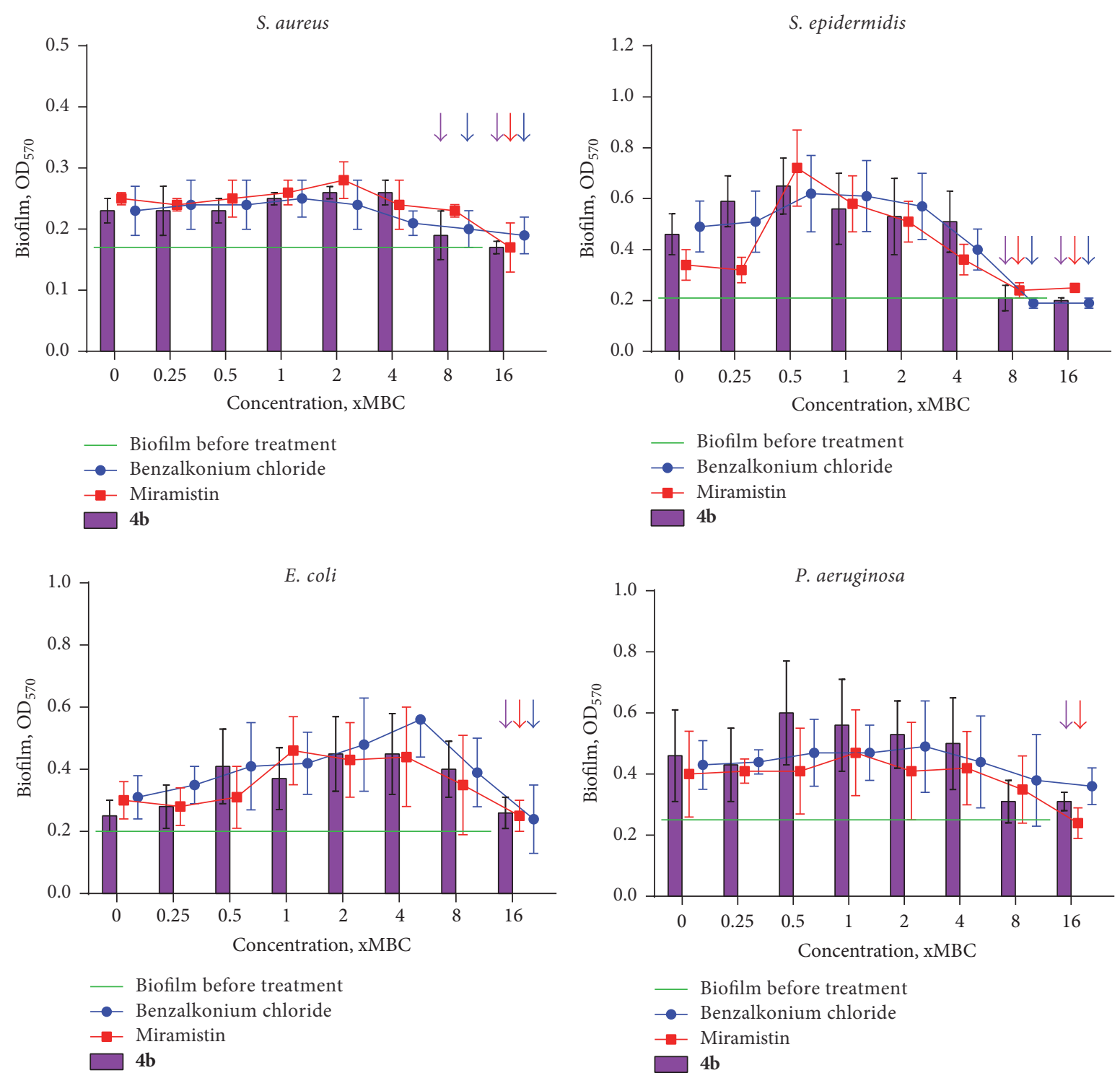

FiguRE 2: The effect of $\mathbf{4 b}$, miramistin, and benzalkonium chloride on bacterial biofilm formation. The 24-h biofilms (green line) were treated with $0.25-16 \times$ MBCs of antimicrobials or $\mathbf{4 b}$ (bars) for $24 \mathrm{~h}$ and then were quantified with crystal violet assay. Data are present as averages from five independent experiments with standard deviations. Arrows indicate no differences with the initial biofilm mass.

control in SOS-chromotest. The optical density at $420 \mathrm{~nm}$ (OD420) was measured, and $\beta$-galactosidase activity was normalized to the amount of cells estimated from the OD600 values. SOS induction factor was calculated as a ratio of $\beta$ galactosidase activity in the presence of compounds and the solvent control (Table 4 ). The concentrations of $\mathbf{4 b}$ were in the range of $0.75-150 \mu \mathrm{g} / \mathrm{mL}$. The tested compound as well as the reference biocides miramistin and benzalkonium chloride led to dose-dependent increase of $\beta$-galactosidase activity suggesting the development of SOS-response in cells at high concentrations. DNA-damaging activity of compound $\mathbf{4 b}$ was similar to that of benzalkonium chloride and significantly lower as compared to that of miramistin under the tested concentrations.
3.1.7. Cytotoxicity. Cytotoxicity of compounds $\mathbf{4 a}, \mathbf{b}$ and the reference antifungal and antibacterial drugs was evaluated in human fibroblast cells (HFC) and human embryonal kidney (HEK-293) cells (Table 5). Fluconazole demonstrated the lowest cytotoxicity among the studied molecules. Compound 4a was more toxic than fluconazole, but less toxic than all other compounds. The leading compound $\mathbf{4 b}$ was more toxic than $\mathbf{4 a}$ and fluconazole, slightly more toxic than terbinafine, and significantly less toxic than miramistin and benzalkonium chloride. The latter were the most cytotoxic in the studied group. For deeper characterization of compounds cytotoxicity, their $\mathrm{CC}_{50} / \mathrm{MBC}$ ratios were calculated with minimal and maximal MBC values established for the bacteria analyzed (Table 5). 


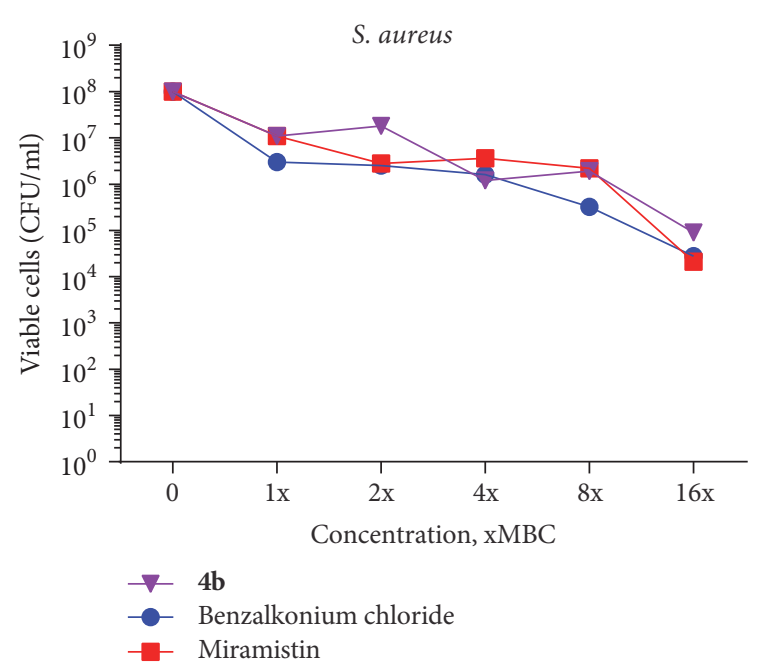

(a)

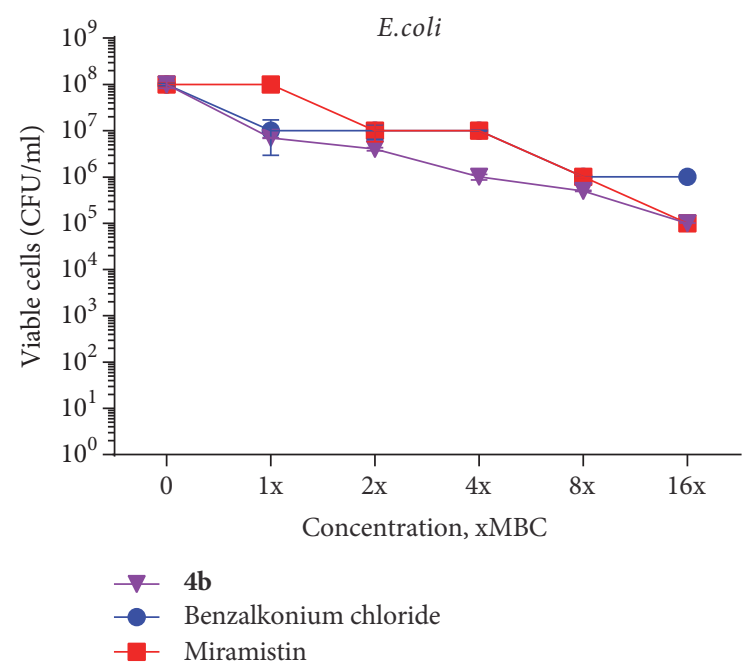

(c)

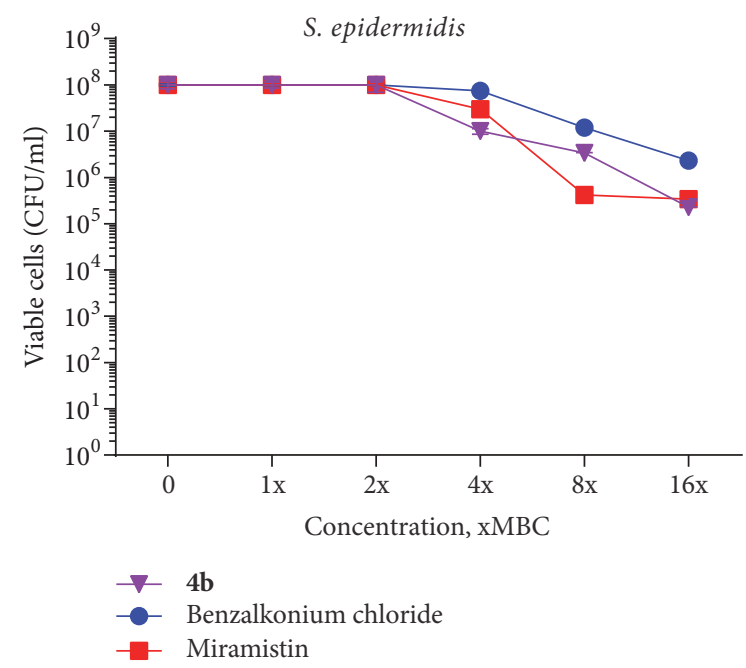

(b)

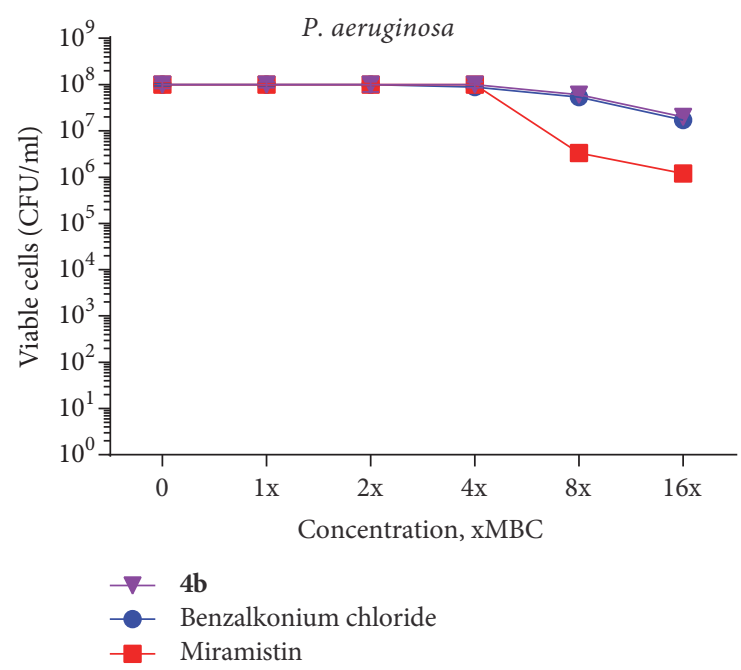

(d)

FIgURE 3: Antimicrobial effect of $\mathbf{4 b}$ on biofilm-embedded bacteria.

\subsection{Discussion}

3.2.1. Antimycotic Activity. Fluconazole is a drug widely used for the treatment of various fungal infections. Despite certain side effects, it has low toxicity and is generally well tolerated, and the recommended therapeutic regimens are very appealing to the patient. However, many fungal pathogens including various Candida species develop resistance to fluconazole. In addition, the data reported in literature and obtained in this work indicate that this drug can be ineffective for the biofilms-associated infections. In this relation, the development of more effective therapeutic agents for the treatment of various forms of candidiasis represents a highly actual task.

To overcome the problems associated with fluconazolebased therapies, in this work we have attempted to design a novel hybrid construction based on quaternary ammonium derivatives of fluconazole and pyridoxine. Our aim was to increase antimycotic activity, including activity against biofilm-forming fungi, and reduce ability of fungal pathogens to develop resistance.

Since the 1930s, quaternary ammonium compounds (QACs) are widely used for the control of bacterial and fungal growth. Broad-spectrum antimicrobial activity [40, 41] has made many QACs such as benzalkonium chloride, miramistin, and cetylpyridinium chloride, the useful hygienic adjuncts in disinfectant formulations, and they have also been used in therapy of patients with local pyoinflammatory processes. QACs can also be active against the main pathogenic fungi, such as Candida albicans [42], Cryptococcus neoformans [43], Saccharomyces cerevisiae [44], and Aspergillus flavus [45].

The underlying idea for introduction of pyridoxine (vitamin B6) moiety into the developed hybrid structures is that the presence of pyridoxine moiety can enhance transmembrane transport of the obtained constructs via several possible mechanisms. First of all, many cells have 
TABLE 3: Mutagenicity of $\mathbf{4 b}$ in the Ames test (ratio, fold increase over the solvent control).

\begin{tabular}{|c|c|c|c|c|c|}
\hline \multirow{2}{*}{ S. typhimurium strain } & \multirow{2}{*}{ Positive control } & \multicolumn{4}{|c|}{ Concentration, $\mu \mathrm{g} / \mathrm{mL}$} \\
\hline & & 0.2 & 0.4 & 0.8 & 1.6 \\
\hline TA98 & $342 \pm 34$ & $0.7 \pm 0.3$ & $1.2 \pm 0.5$ & $0.9 \pm 0.2$ & $0.6 \pm 0.2$ \\
\hline TA100 & $4.6 \pm 1.3$ & $0.7 \pm 0.2$ & $0.8 \pm 0.4$ & $0.4 \pm 0.1$ & $0.4 \pm 0.1$ \\
\hline TA102 & $2.6 \pm 0.9$ & $0.9 \pm 0.3$ & $0.6 \pm 0.3$ & $0.5 \pm 0.2$ & $0.6 \pm 0.1$ \\
\hline TA1535 & $62 \pm 13$ & $0.7 \pm 0.2$ & $0.6 \pm 0.4$ & $0.9 \pm 0.1$ & $0.8 \pm 0.1$ \\
\hline TA1537 & $6 \pm 1.4$ & $0.7 \pm 0.1$ & $0.7 \pm 0.2$ & $0.8 \pm 0.3$ & $0.3 \pm 0.2$ \\
\hline
\end{tabular}

TABLE 4: DNA-damage activity of $\mathbf{4 b}$ in SOS-chromotest (ratio, fold increase over the solvent control).

\begin{tabular}{lcccccc}
\hline Compounds & \multicolumn{5}{c}{ Concentration, $\mu \mathrm{g} / \mathrm{mL}$} \\
& 150 & 75 & 15 & 7.5 & 1.5 & 0.75 \\
\hline 4b & $2.4 \pm 0.5$ & $3.2 \pm 0.6$ & $2.0 \pm 1.3$ & $1.8 \pm 1.4$ & $0.9 \pm 0.6$ & $1.0 \pm 0.4$ \\
Benzalkonium chloride & $5.0 \pm 1.1$ & $2.0 \pm 0.3$ & $1.8 \pm 1.2$ & $1.5 \pm 0.2$ & $1.2 \pm 0.6$ & $1.2 \pm 0.8$ \\
Miramistin & $5.9 \pm 1.1$ & $4.8 \pm 0.7$ & $2.9 \pm 0.6$ & $2.1 \pm 0.9$ & $1.8 \pm 0.8$ & $1.5 \pm 1.0$ \\
Mitomycin C & - & - & - & - & - & $11.7 \pm 2.5$ \\
\hline
\end{tabular}

TABLE 5: Cytotoxicity of $\mathbf{4 a}, \mathbf{b}$ and the reference drugs (mean \pm SD).

\begin{tabular}{|c|c|c|c|c|}
\hline Compounds & $\begin{array}{c}\mathrm{HFC} \\
\mathrm{CC}_{50}, \mu \mathrm{g} / \mathrm{mL}\end{array}$ & $\begin{array}{c}\mathrm{HFC} \\
\mathrm{CC}_{50} / \mathrm{MBC} \\
\end{array}$ & $\begin{array}{c}\text { HEK-293 } \\
\mathrm{CC}_{50}, \mu \mathrm{g} / \mathrm{mL}\end{array}$ & $\begin{array}{l}\text { HEK-293 } \\
\mathrm{CC}_{50} / \mathrm{MBC}\end{array}$ \\
\hline $4 a$ & $274 \pm 124$ & & $1073 \pm 438$ & \\
\hline $4 b$ & $16.8 \pm 2.0$ & $0.5-2$ & $33.1 \pm 11.3$ & $2-4$ \\
\hline Fluconazole & $>2000$ & & $>2000$ & \\
\hline Terbinafine & $41.1 \pm 19.0$ & & $63.0 \pm 12.2$ & \\
\hline Miramistin & $4.1 \pm 0.4$ & $1-2$ & $4.1 \pm 0.8$ & $1-2$ \\
\hline Benzalkonium chloride & $2.1 \pm 0.1$ & $0.5-2$ & $2.0 \pm 0.9$ & $0.5-2$ \\
\hline
\end{tabular}

specific pyridoxine transporters in their membranes (e.g., [20]). Furthermore, vitamin B6 is a cofactor for more than 140 essential enzymatic reactions, and pyridoxine-modified molecules are often recognized by many pathogenic cells and microorganisms as endogenous. As a result, they have increased cellular permeability and increased bioactivity. For example, the development of pyridoxine-modified nanoparticles for efficient intracellular delivery of doxorubicin (DOXB6-SA-NP) was reported [21]. It was demonstrated that the treatment with DOX-B6-SA-NP kept higher doxorubicin accumulation inside the cells than conventional lipid nanoparticles. The positive charge of nanoparticles facilitated the endosomal escape and promoted the nuclear accumulation of the drug. In vitro studies confirmed the enhanced efficacy of DOX-B6-SA-NP in comparison to free doxorubicin and lipid nanoparticles. Intravenous pharmacokinetics and biodistribution studies demonstrated that pyridoxinemodified nanoparticles can significantly prolong the blood circulation time of doxorubicin in the biological system and increase the drug accumulation in the tumor tissue. As compared to free drug, DOX-B6-SA-NP exhibited increased therapeutic efficacy and lower toxicity in animal models. In general, the obtained results suggest that the pyridoxinemodified nanoparticles represent a prospective platform for anticancer drugs delivery.
Another practical reason for introduction of pyridoxinebased cyclic acetals into the developed hybrids is the possibility of easily varying the acetal substituents in order to modify lipophilicity, steric parameters, and other physicochemical properties of the obtained structures.

The obtained results demonstrate that the developed structures have potent antimycotic activity against several fungal pathogens, including C. albicans, T. rubrum, A. fumigatus, and $R$. nigricans with MICs in the range of $1.5-6.25 \mu \mathrm{g} / \mathrm{mL}$ for the leading compound $4 \mathbf{b}$. The latter also inhibited the growth of C. albicans biofilms. Interestingly, fluconazole, the direct analog of the obtained compounds, was almost inactive in this experiment against the mycelial fungi and only moderately active against the clinical strain of C. albicans (MIC $50 \mu \mathrm{g} / \mathrm{mL}$ ).

It is well known that $C$. albicans biofilms are highly resistant to the action of many clinically important antifungal and antimicrobial agents including fluconazole [46, 47]. C. albicans biofilm formation proceeds via at least three developmental phases: (i) early phase (0 to $11 \mathrm{~h})$, involving adhesion of fungal cells to the substrate, (ii) intermediate phase ( $\sim 12$ to $30 \mathrm{~h}$ ), during which the blastospores coaggregate and proliferate, forming communities while producing a carbohydrate-rich extracellular matrix (ECM), and (iii) maturation phase ( 31 to $72 \mathrm{~h}$ ), in which the fungal cells 
are completely encased in a thick ECM [46]. Acquisition of antifungal resistance by $C$. albicans biofilms correlates with the developmental phases of these biofilms. It was reported that at later developmental phases (12 and $48 \mathrm{~h}$ ), biofilms formed by C. albicans typically displayed complete resistance to fluconazole [48].

In this work, we measured the biofilm biomass growth at the maturation phase $(48 \mathrm{~h})$. Compound $\mathbf{4 b}$ demonstrated expressed ability to inhibit growth of biofilm biomass in all concentrations studied as compared to untreated sample (Figure 2). The inhibition was maximal at concentrations more than $400 \mu \mathrm{g} / \mathrm{mL}$, while in the range of $3.1-25 \mu \mathrm{g} / \mathrm{mL}$ the effect was less expressed. In agreement with the literature data, the biofilms formed by the studied clinical isolates of $C$. albicans were resistant to fluconazole at the same experimental conditions (Figure 1). Moreover, in concentrations below $100 \mu \mathrm{g} / \mathrm{mL}$, fluconazole clearly stimulated biofilm growth. The effects of fluconazole stimulated growth of biofilms formed by Candida species were reported in literature (e.g., $[36,49])$. The obtained results indicate that the leading compound $\mathbf{4 b}$ represents a useful candidate for the treatment of candidiasis caused by $C$. albicans biofilms.

3.2.2. Antibacterial Activity. Another interesting and useful property of compound $\mathbf{4 b}$ is ability to inhibit growth of bacterial pathogens. Recently, we described a wide series of phosphonium and ammonium derivatives of pyridoxine $[22,23,50,51]$. Some of the described compounds possessed potent antibacterial activity with minimum inhibitory concentrations (MICs) in the range of $0.5-64 \mu \mathrm{g} / \mathrm{mL}$. These results encouraged us to test the quaternary ammonium derivatives $\mathbf{4 a}, \mathbf{b}$ in vitro for their ability to inhibit growth of a number of bacterial pathogens. We have observed that the antibacterial activity of $\mathbf{4 b}$ was comparable to that of the two widely used quaternary ammonium salts, benzalkonium chloride and miramistin. In general, compound $\mathbf{4 b}$ efficiently inhibited the growth of Gram-positive bacteria while exhibiting less efficiency against Gram-negative ones suggesting a different mechanism of antimicrobial activity against these two groups of microorganisms. In most cases the MBC/MIC ratio was found to be $2-4$, suggesting that $4 \mathrm{~b}$ exhibits biocidal rather than biostatic properties.

According to literature data [52], QACs generally act by disrupting the cytoplasmic and outer membrane lipid bilayers through association of the positively charged quaternary nitrogen with the anionic head groups of acidic phospholipids and interaction of the lipophilic tail with the hydrophobic membrane core. As a result, QACs form mixed-micelle aggregates with hydrophobic membrane components leading thereby to membrane solubility and cell lysis because of generalized and progressive leakage of cytoplasmic materials. At the same time, other biomolecular complexes within the bacterial and fungal cells are potential targets for action of cationic surfactants. For example, a correlation of antifungal activity with fungal phospholipase inhibition has been described for a series of bis-quaternary ammonium salts [43].
To gain insight into possible mechanism of action of compound $\mathbf{4 b}$, its activity has been tested on six bacterial strains from the same panel of pathogens in the presence of $\mathrm{CaCl}_{2}$ [38]. The mechanism of action of the membrane damaging drugs is often related to removal of $\mathrm{Ca}^{2+}$ from the cellular membranes. $\mathrm{Ca}^{2+}$ ions stabilize membranes by cross-linking of the negatively charged head groups of lipids, and this effect plays an important structural role in the integrity of the outer lipopolysaccharide layer and the cell walls of bacterial cells. Therefore, possible modification of antibacterial activity of the tested compound by $\mathrm{Ca}^{2+}$ ions may indicate that it exerts its antimicrobial activity by causing cell wall damage.

In accordance with this hypothesis, we have observed that the MIC values of $\mathbf{4 b}$ in the presence of $\mathrm{Ca}^{2+}$ ions were significantly increased for both Gram-positive and Gramnegative strains $(>64 \mu \mathrm{g} / \mathrm{mL}$ as compared to $1-32 \mu \mathrm{g} / \mathrm{mL}$ under $\mathrm{Ca}^{2+}$-free conditions) (Table 2 ). The observed activity decrease is probably related to the membrane-stabilizing effect. The increased concentration of $\mathrm{Ca}^{2+}$ ions in the extracellular space prevents their removal from the cell upon the action of the tested compounds. Therefore, it can be suggested that the cell wall damage associated with the removal of $\mathrm{Ca}^{2+}$ ions is one of the possible mechanisms of their antibacterial activity. Similar observations have been reported in our recent paper [53] for a series of quaternary bis-phosphonium salts of pyridine derivatives, which exhibited broad-spectrum antibacterial activity against Grampositive pathogens including methicillin-resistant strains of S. aureus.

So far, no specific target has been identified for most QACs; it is assumed that the effect is rather generalized than specific to one target. However, as discussed in literature [52], there should be some target specificities, for example, as shown for the bis-quaternary bis-naphthalimide MT02 [54], because the activity of QACs toward different bacterial species varies substantially and cannot be explained simply by the structure of cationic and hydrophobic portions [55]. It is therefore possible that compound $\mathbf{4 b}$ exerts membrane damage, leading to disruption of the cell envelope and arresting intracellular activity by binding targets in the cytoplasm. The above described antibacterial effects in the presence of $\mathrm{Ca}^{2+}$ ions suggest that $4 \mathbf{b}$ interacts with bacterial membranes. However, the role of intracellular targets in its antibacterial action remains unclear. Pyridoxine molecule is a wellestablished cofactor for many enzymes. Therefore, pyridoxine derivatives can participate in many intracellular interactions thus leading to enhanced or more specific antibacterial action. The observed effect of $\mathbf{4} \mathbf{b}$ in the SOS-chromotest on S. typhimurium may suggest some specific interaction with DNA; however, this hypothesis requires further experimental investigation.

It was also observed that Gram-positive bacteria are generally more sensitive to $\mathbf{4 b}$ than Gram-negative bacteria, which is in agreement with literature data on QACs [52].

According to our recent report, quaternary ammonium pyridoxine derivatives are able to penetrate the bacterial biofilms and efficiently eradicate them [28]. Therefore, it was 
interesting to evaluate capability of $\mathbf{4 b}$ to target the biofilmembedded bacterial cells. To address this issue, four common human resident Gram-positive (S. aureus, S. epidermidis) and Gram-negative (E. coli and $P$. aeruginosa) bacteria causing nosocomial infections and forming rigid biofilms on tissues and abiotic surfaces were chosen as model objects. The bacterial strains were grown in basal medium (BM) broth in 24-well plates for 72 hours to obtain rigid biofilms. Then the wells were washed, filled with fresh BM containing different concentrations of antimicrobials, and incubated for the next 24 hours. The amount of colony-forming units (CFUs) in the biofilm was quantified using a drop plate approach. Both benzalkonium chloride and miramistin were active against the biofilm-embedded staphylococci (Figures 3(a) and 3(b)) reducing the CFUs amount by 3 orders of magnitude at (4-6) $\times \mathrm{MBC}$ (minimum bactericidal concentration). At the same time, both drugs were less effective against $E$. coli (Figure 3(c)) and almost inactive against $P$. aeruginosa (Figure $3(\mathrm{~d})$ ). The activity of $\mathbf{4 b}$ in these experiments was not so expressed (Figure 3). Thus, it was inactive against S. epidermidis and $P$. aeruginosa strains even at $10 \times \mathrm{MBC}$ and only moderately active against $S$. aureus and $E$. coli. At the same time, although 4b was not so efficient in eradicating the studied biofilms, the observed activity against $S$. aureus and E. coli suggests its ability to penetrate through the biofilm wall. Taking into account the fact that MIC of many antibiotics against biofilmembedded bacteria increases up to 1000 -fold as compared to their planktonic forms, it can also be suggested that further structural modification can increase the activity.

3.2.3. Safety Issues. The results of the Ames test suggest the absence of mutagenic potential of $\mathbf{4 b}$. At the same time, the tested compound as well as the reference biocides miramistin and benzalkonium chloride led to dose-dependent increase of $\beta$-galactosidase activity suggesting the development of SOS-response in cells at high concentrations. DNA-damaging activity of compound $\mathbf{4 b}$ was similar to that of benzalkonium chloride and significantly lower as compared to that of miramistin.

The cytotoxicity studies on human fibroblast cells and human embryonal kidney cells demonstrate that compound 4b was more toxic than the reference antifungal drugs (fluconazole and terbinafine), but significantly less toxic than miramistin and benzalkonium chloride, the effective antiseptics for the local treatment of infected wounds with declared low side effects $[56,57]$. In particular, $\mathrm{CC}_{50}$ value of benzalkonium chloride for the normal human fibroblasts was reported to be $6.7 \mu \mathrm{g} / \mathrm{mL}$, with $\mathrm{CC}_{50} / \mathrm{MBC}$ ratio of 0.05 [58]. In our studies, $\mathrm{CC}_{50}$ of benzalkonium chloride was found a bit less $(2.1 \mu \mathrm{g} / \mathrm{mL})$, while the $\mathrm{CC}_{50} / \mathrm{MBC}$ for both human fibroblasts and 2 HEK-293 cells was in range of 0.5-2 (Table 5). For $\mathbf{4 b}$ the $\mathrm{CC}_{50} / \mathrm{MBC}$ ratio was also found in a range of 0.5-2 for human fibroblasts and 2-4 for HEK293 cells, suggesting that it has at least similar therapeutic index with benzalkonium chloride, which is widely used as a biocide for outer treatment $[56,57,59]$.

In general, comparative evaluation of activity and safety parameters for compound $\mathbf{4 b}$ and the reference antifungal and antibacterial drugs suggest promising potential of the obtained chemotype in the design of novel broad-spectrum antimicrobial agents.

\section{Conclusion}

In this work, we have synthesized two novel quaternary ammonium salts $\mathbf{4 a}, \mathbf{b}$, bis-triazolium derivatives of fluconazole and pyridoxine, and studied their antimycotic and antibacterial activity, cytotoxicity, and genotoxicity. The leading compound $\mathbf{4 b}$ demonstrated potent antimycotic activity against several fungal pathogens, including C. albicans, T. rubrum, A. fumigatus, and R. nigricans with MICs in the range of $1.5-6.25 \mu \mathrm{g} / \mathrm{mL}$. It also inhibited the growth of $C$. albicans biofilms. Under the same experimental conditions, fluconazole was inactive or moderately active against the studied fungal pathogens. In addition, $\mathbf{4 b}$ demonstrated high antibacterial activity on a panel of Gram-positive and Gram-negative bacterial strains with MICs in the range of $1-32 \mu \mathrm{g} / \mathrm{mL}$, which was comparable or better than that of the reference antibacterial drugs, benzalkonium chloride, and miramistin. Antibacterial activity studies in the presence of $\mathrm{CaCl}_{2}$ suggested that the cell wall damage associated with the removal of $\mathrm{Ca}^{2+}$ ions from the bacterial membrane is one of the possible mechanisms of antibacterial activity. In contrast to many antimicrobials, $\mathbf{4 b}$ was also active against biofilm-embedded staphylococci and Escherichia coli. While no biofilm structure destruction occurred, $\mathbf{4 b}$ was able to diffuse into the matrix and reduce the number of colonyforming units by three orders of magnitude at $16 \times \mathrm{MBC}$. The Ames test in S. typhimurium showed the lack of DNA-damage activity for $\mathbf{4 b}$; at the same time, it showed some mutagenic potential in the SOS-chromotest comparable to that of benzalkonium chloride. Cytotoxicity studies on human skin fibroblasts and embryonic kidney cells demonstrated that $\mathbf{4 b}$ was more toxic than $\mathbf{4 a}$ and fluconazole, slightly more toxic than terbinafine, and significantly less toxic than miramistin and benzalkonium chloride. The obtained results make the described chemotype a promising starting point for the development of new antimicrobial therapies with a broad spectrum of antifungal and antibacterial activity and ability to inhibit biofilm growth.

\section{Conflicts of Interest}

The authors declare that there are no conflicts of interest regarding the publication of this manuscript.

\section{Acknowledgments}

This work was supported by the Russian Science Foundation, Grant no. 15-14-00046, and by the Programs of Competitive Growth of Kazan Federal University and I.M. Sechenov First Moscow State Medical University. 


\section{References}

[1] M. V. Castelli, M. G. Derita, and S. N. López, "Novel antifungal agents: a patent review (2013-present)," Expert Opinion on Therapeutic Patents, vol. 27, no. 4, pp. 415-426, 2017.

[2] R. L. Harvey and J. P. Myers, "Nosocomial fungemia in a large community teaching hospital," JAMA Internal Medicine, vol. 147, no. 12, pp. 2117-2120, 1987.

[3] Y. Tong and J. Tang, "Candida albicans infection and intestinal immunity," Microbiological Research, vol. 198, pp. 27-35, 2017.

[4] M. Ruhnke, "Mucosal and systemic fungal infections in patients with AIDS: prophylaxis and treatment," Drugs, vol. 64, no. 11, pp. 1163-1180, 2004.

[5] M. A. Al-Fattani and L. J. Douglas, "Biofilm matrix of Candida albicans and Candida tropicalis: chemical composition and role in drug resistance," Journal of Medical Microbiology, vol. 55, no. 8, pp. 999-1008, 2006.

[6] S. Tobudic, C. Kratzer, A. Lassnigg, and E. Presterl, "Antifungal susceptibility of Candida albicans in biofilms," Mycoses, vol. 55, no. 3, pp. 199-204, 2012

[7] H. T. Taff, K. F. Mitchell, J. A. Edward, and D. R. Andes, "Mechanisms of Candida biofilm drug resistance," Future Microbiology, vol. 8, no. 10, pp. 1325-1337, 2013.

[8] M. S. Tuttle, E. Mostow, P. Mukherjee et al., "Characterization of bacterial communities in venous insufficiency wounds by use of conventional culture and molecular diagnostic methods," Journal of Clinical Microbiology, vol. 49, no. 11, pp. 3812-3819, 2011.

[9] F. Z. Hu and G. D. Ehrlich, "Population-level virulence factors amongst pathogenic bacteria: relation to infection outcome," Future Microbiology, vol. 3, no. 1, pp. 31-42, 2008.

[10] M. K. Kathiravan, A. B. Salake, A. S. Chothe et al., "The biology and chemistry of antifungal agents: a review, Bioorganic \& Medicinal Chemistry, vol. 20, no. 19, pp. 5678-5698, 2012.

[11] L. R. Peyton, S. Gallagher, and M. Hashemzadeh, "Triazole antifungals: a review," Drugs of Today, vol. 51, no. 12, pp. 705718, 2015.

[12] X. Che, C. Sheng, W. Wang et al., "New azoles with potent antifungal activity: design, synthesis and molecular docking," European Journal of Medicinal Chemistry, vol. 44, no. 10, pp. 4218-4226, 2009.

[13] S. G. Whaley, E. L. Berkow, J. M. Rybak, A. T. Nishimoto, K. S. Barker, and P. D. Rogers, "Azole antifungal resistance in Candida albicans and emerging non-albicans Candida Species," Frontiers in Microbiology, vol. 7, article 2173, 2017.

[14] S. Sobue, K. Tan, L. Shaw, G. Layton, and R. Hust, "Comparison of the pharmacokmetics of fosfluconazole and fluconazole after single intravenous administration of fosfluconazole in healthy Japanese and Caucasian volunteers," European Journal of Clinical Pharmacology, vol. 60, no. 4, pp. 247-253, 2004.

[15] N.-H. Nam, S. Sardari, M. Selecky, and K. Parang, "Carboxylic acid and phosphate ester derivatives of fluconazole: synthesis and antifungal activities," Bioorganic \& Medicinal Chemistry, vol. 12, no. 23, pp. 6255-6269, 2004.

[16] G.-P. Yu, L.-Z. Xu, X. Yi, W.-Z. Bi, Q. Zhu, and Z.-W. Zhai, "Synthesis and fungicidal evaluation of 2-arylphenyl ether-3-(1 H-1,2,4-triazol-1-yl)propan-2-ol derivatives," Journal of Agricultural and Food Chemistry, vol. 57, no. 11, pp. 4854-4860, 2009.

[17] A. Bentley, M. Butters, S. P. Green et al., "The discovery and process development of a commercial route to the water soluble prodrug, fosfluconazole," Organic Process Research \& Development, vol. 6, no. 2, pp. 109-112, 2002.
[18] K. M. Hindi, T. J. Siciliano, S. Durmus et al., "Synthesis, stability, and antimicrobial studies of electronically tuned silver acetate N-heterocyclic carbenes," Journal of Medicinal Chemistry, vol. 51, no. 6, pp. 1577-1583, 2008.

[19] Y.-Y. Zhang, J.-L. Mi, C.-H. Zhou, and X.-D. Zhou, "Synthesis of novel fluconazoliums and their evaluation for antibacterial and antifungal activities," European Journal of Medicinal Chemistry, vol. 46, no. 9, pp. 4391-4402, 2011.

[20] N. Szydlowski, L. Bürkle, L. Pourcel, M. Moulin, J. Stolz, and T. B. Fitzpatrick, "Recycling of pyridoxine (vitamin B6) by PUP1 in Arabidopsis," The Plant Journal, vol. 75, no. 1, pp. 40-52, 2013.

[21] S. Sharma, A. Verma, J. Singh et al., "Vitamin B6 tethered endosomal $\mathrm{PH}$ responsive lipid nanoparticles for triggered intracellular release of doxorubicin," ACS Applied Materials \& Interfaces, vol. 8, no. 44, pp. 30407-30421, 2016.

[22] S. V. Sapozhnikov, N. V. Shtyrlin, A. R. Kayumov et al., "New quaternary ammonium pyridoxine derivatives: synthesis and antibacterial activity," Medicinal Chemistry Research, vol. 26, no. 12, pp. 3188-3202, 2017.

[23] M. V. Pugachev, N. V. Shtyrlin, S. V. Sapozhnikov et al., "Bisphosphonium salts of pyridoxine: the relationship between structure and antibacterial activity," Bioorganic and Medicinal Chemistry, vol. 21, no. 23, pp. 7329-7341, 2013.

[24] G. A. O'Toole and R. Kolter, "Initiation of biofilm formation in Pseudomonas fluorescens WCS365 proceeds via multiple, convergent signalling pathways: a genetic analysis," Molecular Microbiology, vol. 28, no. 3, pp. 449-461, 1998.

[25] G. Ramage, K. VandeWalle, B. L. Wickes, and J. L. López-Ribot, "Characteristics of biofilm formation by Candida albicans," Revista Iberoamericana de Micología, vol. 18, no. 4, pp. 163-170, 2001.

[26] R. Leclercq, R. Cantón, D. F. J. Brown et al., "EUCAST expert rules in antimicrobial susceptibility testing," Clinical Microbiology and Infection, vol. 19, no. 2, pp. 141-160, 2013.

[27] B. Herigstad, M. Hamilton, and J. Heersink, "How to optimize the drop plate method for enumerating bacteria," Journal of Microbiological Methods, vol. 44, no. 2, pp. 121-129, 2001.

[28] A. R. Kayumov, A. A. Nureeva, E. Y. Trizna et al., "New derivatives of pyridoxine exhibit high antibacterial activity against biofilm-embedded staphylococcus cells," BioMed Research International, vol. 2015, Article ID 890968, 10 pages, 2015.

[29] J. H. Miller, In Experiments in Molecular Genetics, Cold Spring Harbor Laboratory Press, New York, Ny, USA, 1972.

[30] K. Fedorova, A. Kayumov, K. Woyda, O. Ilinskaja, and K. Forchhammer, "Transcription factor TnrA inhibits the biosynthetic activity of glutamine synthetase in Bacillus subtilis," FEBS Letters, vol. 587, no. 9, pp. 1293-1298, 2013.

[31] J. McCann and B. N. Ames, "A simple method for detecting environmental carcinogens as mutagens," Annals of the New York Academy of Sciences, vol. 271, pp. 5-13, 1976.

[32] D. A. Stevens, T. C. White, D. S. Perlin, and C. P. Selitrennikoff, "Studies of the paradoxical effect of caspofungin at high drug concentrations," Diagnostic Microbiology and Infectious Disease, vol. 51, no. 3, pp. 173-178, 2005.

[33] G. Chamilos, R. E. Lewis, N. Albert, and D. P. Kontoyiannis, "Paradoxical effect of echinocandins across Candida species in vitro: evidence for Echinocandin-Specific and Candida speciesrelated differences," Antimicrobial Agents and Chemotherapy, vol. 51, no. 6, pp. 2257-2259, 2007. 
[34] K. V. Clemons, M. Espiritu, R. Parmar, and D. A. Stevens, "Assessment of the paradoxical effect of caspofungin in therapy of candidiasis," Antimicrobial Agents and Chemotherapy, vol. 50, no. 4, pp. 1293-1297, 2006.

[35] C. J. Walraven, S. M. Bernardo, N. P. Wiederhold, and S. A. Lee, "Paradoxical antifungal activity and structural observations in biofilms formed by echinocandin-resistant Candida albicans clinical isolates," Medical Mycology, vol. 52, no. 2, pp. 131-139, 2014.

[36] E. M. Maiolo, U. F. Tafin, O. Borens, and A. Trampuz, "Activities of fluconazole, caspofungin, anidulafungin, and amphotericin $\mathrm{B}$ on planktonic and biofilm candida species determined by microcalorimetry," Antimicrobial Agents and Chemotherapy, vol. 58, no. 5, pp. 2709-2717, 2014.

[37] F. C. Bizerra, A. S. A. Melo, E. Katchburian et al., "Changes in cell wall synthesis and ultrastructure during paradoxical growth effect of caspofungin on four different candida species," Antimicrobial Agents and Chemotherapy, vol. 55, no. 1, pp. 302310, 2011.

[38] T. Das, S. Sehar, L. Koop et al., "Influence of calcium in extracellular DNA mediated bacterial aggregation and biofilm formation," PLoS ONE, vol. 9, no. 3, Article ID e91935, 2014.

[39] Y. Oda, S.-I. Nakamura, I. Oki, T. Kato, and H. Shinagawa, "Evaluation of the new system (umu-test) for the detection of environmental mutagens and carcinogens," Mutation Research, vol. 147, no. 5, pp. 219-229, 1985.

[40] K. P. C. Minbiole, M. C. Jennings, L. E. Ator et al., "From antimicrobial activity to mechanism of resistance: the multifaceted role of simple quaternary ammonium compounds in bacterial eradication," Tetrahedron, vol. 72, no. 25, pp. 3559-3566, 2016.

[41] E. Obłak, A. Piecuch, A. Krasowska, and J. Łuczyński, "Antifungal activity of gemini quaternary ammonium salts," Microbiological Research, vol. 168, no. 10, pp. 630-638, 2013.

[42] N. Lincopan and A. M. Carmona-Ribeiro, "Lipid-covered drug particles: Combined action of dioctadecyldimethylammonium bromide and amphotericin B or miconazole," Journal of Antimicrobial Chemotherapy, vol. 58, no. 1, pp. 66-75, 2006.

[43] C. K. L. Ng, D. Obando, F. Widmer, L. C. Wright, T. C. Sorrell, and K. A. Jolliffe, "Correlation of antifungal activity with fungal phospholipase inhibition using a series of bisquaternary ammonium salts," Journal of Medicinal Chemistry, vol. 49, no. 2, pp. 811-816, 2006.

[44] E. Obłak, A. Gamian, R. Adamski, and S. Ułaszewski, "The physiological and morphological phenotype of a yeast mutant resistant to the quaternary ammonium salt $\mathrm{N}$ (dodecyloxycarboxymethyl)-N,N,N-trimethyl ammonium chloride," Cellular \& Molecular Biology Letters, vol. 15, no. 2, pp. 215-233, 2010.

[45] M. H. El-Newehy, H. El-Hamshary, S. S. Al-Deyab, and A. Abdel-Megeed, "Synthesis of quaternized amine-terminated polyacrylonitrile and their antimicrobial assessment," Journal of Macromolecular Science, Part A Pure and Applied Chemistry, vol. 51, no. 6, pp. 527-537, 2014.

[46] J. Chandra, D. M. Kuhn, P. K. Mukherjee, L. L. Hoyer, T. McCormick, and M. A. Ghannoum, "Biofilm formation by the fungal pathogen Candida albicans: development, architecture, and drug resistance," Journal of Bacteriology, vol. 183, no. 18, pp. 5385-5394, 2001.

[47] J. Morschhäuser, "The development of fluconazole resistance in Candida albicans - an example of microevolution of a fungal pathogen," Journal of Microbiology, vol. 54, no. 3, pp. 192-201, 2016.
[48] P. K. Mukherjee, J. Chandra, D. M. Kuhn, and M. A. Ghannoum, "Mechanism of fluconazole resistance in Candida albicans biofilms: phase-specific role of efflux pumps and membrane sterols," Infection and Immunity, vol. 71, no. 8, pp. 4333-4340, 2003.

[49] C. F. Rodrigues and M. Henriques, "Oral mucositis caused by Candida glabrata biofilms: failure of the concomitant use of fluconazole and ascorbic acid," Therapeutic Advances in Infectious Disease, vol. 4, no. 1, pp. 10-17, 2017.

[50] M. V. Pugachev, N. V. Shtyrlin, L. P. Sysoeva et al., "Synthesis and antibacterial activity of novel phosphonium salts on the basis of pyridoxine," Bioorganic \& Medicinal Chemistry, vol. 21, no. 14, pp. 4388-4395, 2013.

[51] N. V. Shtyrlin, S. V. Sapozhnikov, S. A. Koshkin et al., "Synthesis and antibacterial activity of novel quaternary ammonium pyridoxine derivatives," Medicinal Chemistry, vol. 11, no. 7, pp. 656665, 2015.

[52] M. Tischer, G. Pradel, K. Ohlsen, and U. Holzgrabe, "Quaternary ammonium salts and their antimicrobial potential: targets or nonspecific interactions?" ChemMedChem, vol. 7, no. 1, pp. 22-31, 2012.

[53] E. V. Nikitina, M. I. Zeldi, M. V. Pugachev et al., "Antibacterial effects of quaternary bis-phosphonium and ammonium salts of pyridoxine on Staphylococcus aureus cells: a single base hitting two distinct targets?" World Journal of Microbiology and Biotechnology, vol. 32, no. 1, article 5, pp. 1-7, 2016.

[54] L. González-Bulnes and J. Gallego, "Indirect effects modulating the interaction between DNA and a cytotoxic bisnaphthalimide reveal a two-step binding process," Journal of the American Chemical Society, vol. 131, no. 22, pp. 7781-7791, 2009.

[55] H. H. Locher, D. Ritz, P. Pfaff et al., "Dimers of nostocarboline with potent antibacterial activity," Chemotherapy, vol. 56, no. 4, pp. 318-324, 2010.

[56] I. L. Bernstein, "Is the use of benzalkonium chloride as a preservative for nasal formulations a safety concern? A cautionary note based on compromised mucociliary transport," The Journal of Allergy and Clinical Immunology, vol. 105, no. 1 I, pp. 39-44, 2000.

[57] C. Fromm-Dornieden, J.-D. Rembe, N. Schäfer, J. Böhm, and E. K. Stuermer, "Cetylpyridinium chloride and miramistin as antiseptic substances in chronic wound management-prospects and limitations," Journal of Medical Microbiology, vol. 64, no. 4, pp. 407-414, 2015.

[58] O. Damour, S. Zhi Hua, F. Lasne, M. Villain, P. Rousselle, and C. Collombel, "Cytotoxicity evaluation of antiseptics and antibiotics on cultured human fibroblasts and keratinocytes," Burns, vol. 18, no. 6, pp. 479-485, 1992.

[59] N. Akimitsu, H. Hamamoto, R.-I. Inoue et al., "Increase in resistance of methicillin-resistant Staphylococcus aureus to beta-lactams caused by mutations conferring resistance to benzalkonium chloride, a disinfectant widely used in hospitals," Antimicrobial Agents and Chemotherapy, vol. 43, no. 12, pp. 3042-3043, 1999. 

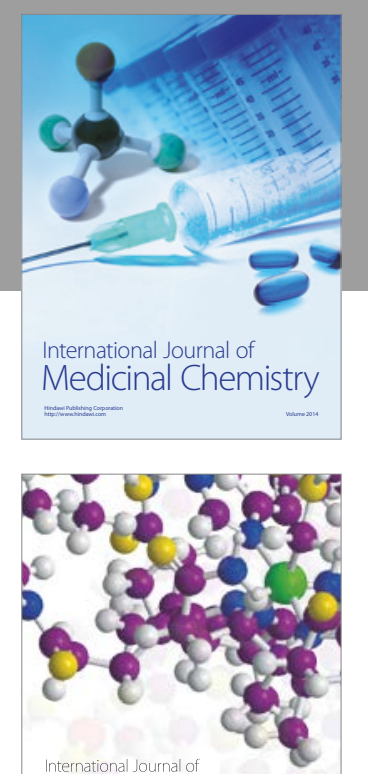

Carbohydrate Chemistry

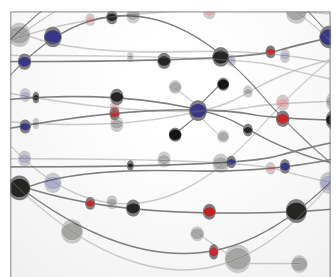

The Scientific World Journal
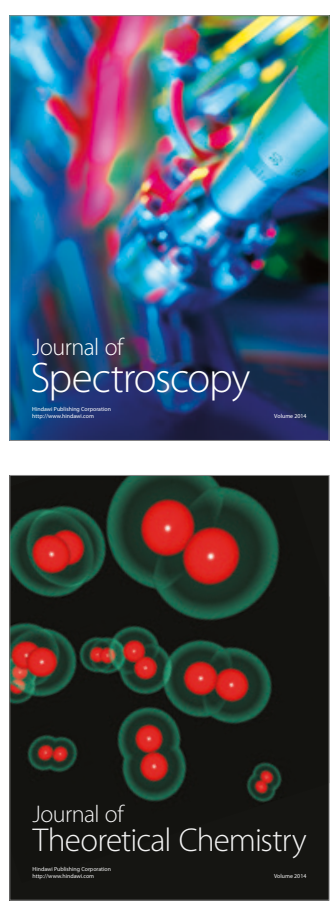
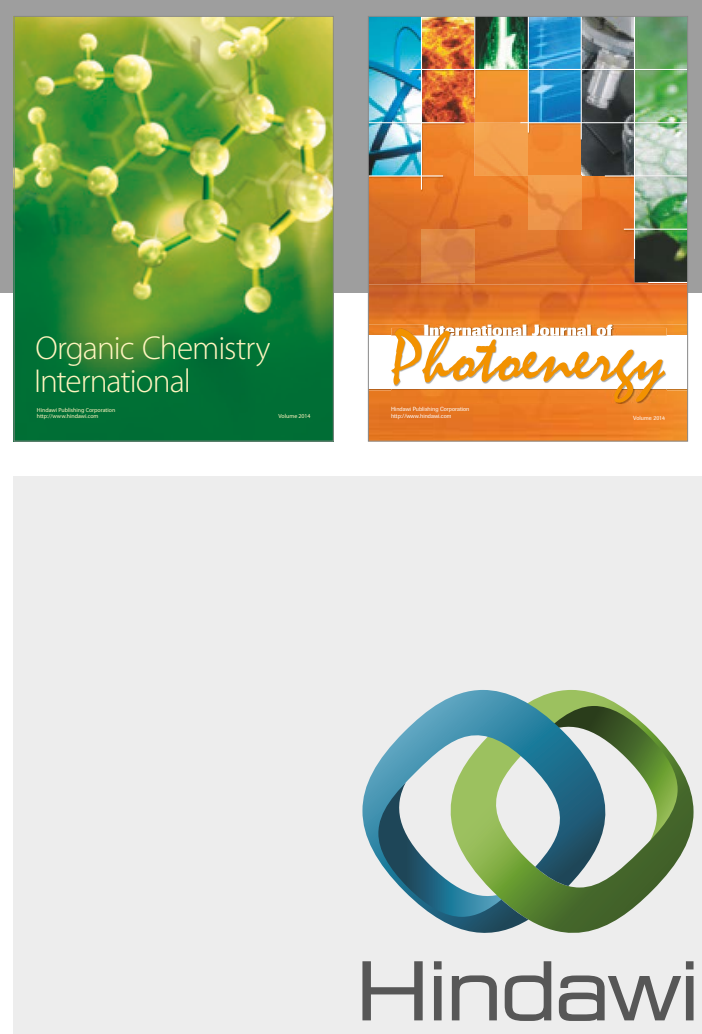

Submit your manuscripts at

https://www.hindawi.com

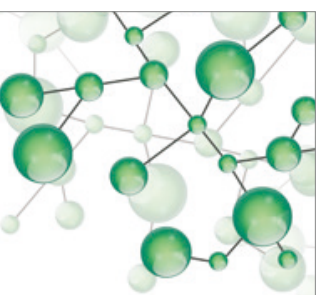

International Journal of

Inorganic Chemistry

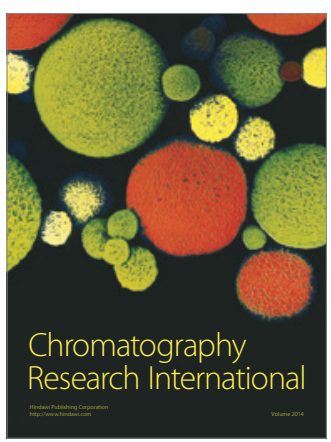

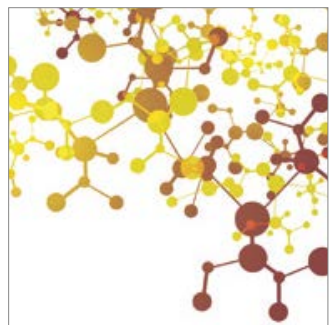

Applied Chemistry
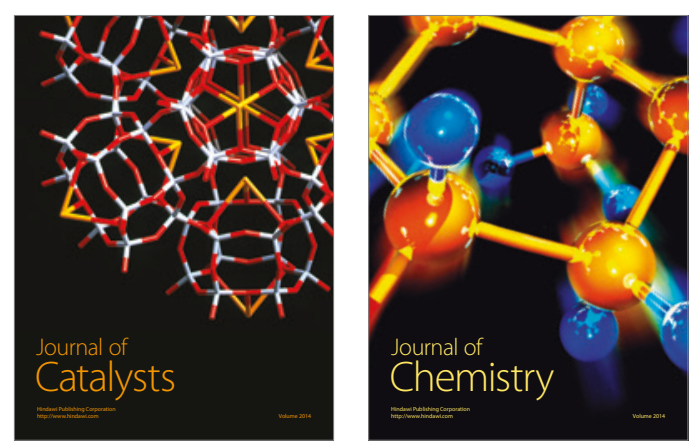
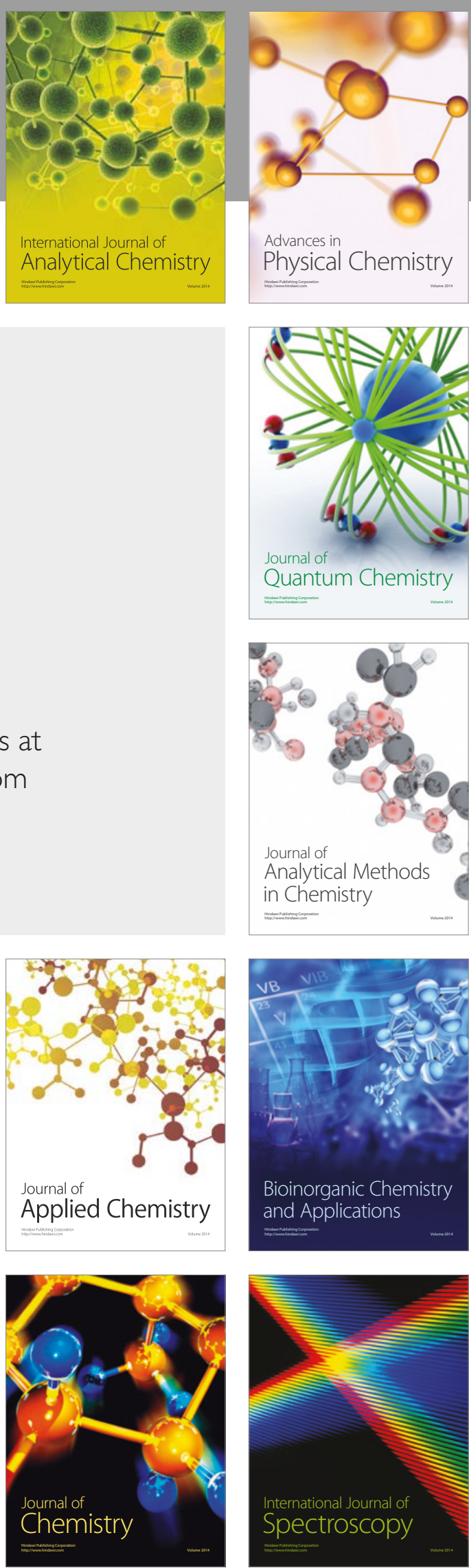